\title{
Rethinking Health Professionals' Motivation to Do Research: A Systematic Review
}

\author{
Louisa M D'Arrietta $\mathbb{1}^{1,2}$ \\ Venkat $N$ Vangaveti ${ }^{1}$ \\ Melissa J Crowe ${ }^{3}$ \\ Bunmi S Malau-Aduli (iD) \\ 'College of Medicine and Dentistry, \\ James Cook University, Townsville, \\ Queensland, Australia; ${ }^{2}$ Library Services, \\ Townsville University Hospital, \\ Townsville Hospital and Health Service, \\ Townsville, Queensland, Australia; \\ ${ }^{3}$ Division of Tropical Health and \\ Medicine, James Cook University, \\ Queensland, Australia
}

Background: Health professionals' engagement in translational health and medical research (HMR) is fundamental to evidence-based practice leading to better patient health outcomes. However, there is a decline in the number of health professionals undertaking research which has implications for patient health and the economy. Informed by the motivation-based expectancyvalue-cost (EVC) and self determination theories (SDT), this systematic literature review examined the barriers and facilitators of health professionals' (HPs) motivation to undertake research.

Methods: The literature was searched between 2011 and 2021 for relevant peer-reviewed articles written in English, using CINAHL Complete, Informit, Medline Ovid, Medline (PubMed), Scopus, Web of Science and Google Scholar databases. This systematic review was performed and reported in accordance with the PRISMA guidelines.

Results: Identified barriers to HPs' engagement with research included the lack of knowledge, skills, and competence to conduct research, lack of protected research time, lack of funding and lack of organisational support. Integration of the findings of this review based on the EVC and SDT theories indicate that research capacity, ie, expectancy and competence is highly influenced by attitude, ie, the type of value (attainment, intrinsic or utility) and connection attributed to research. HPs who had very positive attitude towards research demonstrated all three values and were keen to take up research despite the barriers. Those who had a positive attitude were only motivated to do research because of its utility value and did not necessarily see it as having personal relevance for themselves. HPs who were unmotivated did not see any personal connection or relatedness to the research experience and saw no value in research.

Conclusion: The attitude HPs hold in their value of research is a catalyst for motivation or amotivation to engage in research as it directly influences the relevance of barriers. Facilitators that expedite the research journey have been attributed to research training, mentorship programs and supportive organisational research culture. Motivation of HPs explored through EVC and SDT is critical to the maintenance of a research culture and the clinician-researcher development pipeline.

Keywords: barriers, facilitators, expectancy-value theory, EVC, self-determination theory, SDT, health professionals, motivation

\section{Introduction}

Health professionals (HPs), including doctors, nurses, midwives, and allied health professionals (AHPs) who undertake research have been referred to in the literature under various titles including, clinician researcher ${ }^{1}$ clinician investigator $^{2}$ and physician-researcher. ${ }^{3}$ This group of HPs spend time as both active clinicians and researchers and they engage in translational health and medical research (HMR) to address the issues they see in clinical practice. ${ }^{4}$ HP led research is important because it fosters evidence-based clinical practice and improved health outcomes
Correspondence: Louisa M D'Arrietta College of Medicine and Dentistry, James Cook University, Townsville, Queensland 48 II, Australia

Tel $+6 I 7478 \mid 4060$

Fax +6I 747796371

Email louisa.darrietta@jcu.edu.au 
for patients. ${ }^{5}$ For example, research on chronic diseases has significantly contributed to better health outcomes and improved quality of life for people across Australia and globally. ${ }^{6}$ In addition to the patient health benefits, employment of those engaged in HMR has resulted in continued productivity due to better health outcomes and financial benefits from new medicines and technology. HMR has helped Australia become a leading economy of the 21 st century returning an increasing net benefit of $\$ 8.2$ billion, returning $\$ 3.90$ for every dollar invested ${ }^{6}$ and from 2000 to 2015, National Health and Medical Research Council (NHMRC)-funded research saved the Australian health system $\$ 23.4$ billion. $^{6}$ Despite the benefits of research to the economy and health benefits to patients there still exists a dearth of HP researchers.

There has been an ongoing global concern that the number of HPs undertaking research is declining. ${ }^{7}$ The seminal paper by Wyngaarden, "The clinical investigator as an endangered species" addressed this concern over 40 years ago. ${ }^{9,10}$ Recent international trends from the USA, ${ }^{7,11,12}$ Canada, ${ }^{13}$ UK, ${ }^{14}$ Sweden, ${ }^{15}$ Africa, ${ }^{16}$ Singapore, ${ }^{17}$ Pakistan $^{18}$ and Saudi Arabia ${ }^{19}$ still indicate a decline in the number of young researchers replacing an aging workforce. For example, in the US, the fraction of physician-researchers has reduced from $4.7 \%$ in the $1980 \mathrm{~s}$ to approximately $1.5 \%$ currently. ${ }^{20}$ In New Zealand (NZ) and Australia there exists a similar scenario, with the number of individuals training in medical research decreasing or stagnating over the past few decades. ${ }^{21-23}$ The Australian Institute of Health and Welfare (AIHW) reported a decline in the proportion of employed Australian doctors who identified primarily as researchers from $2.1 \%$ in 2002 to $1.5 \%$ in $2010 .^{24,25}$ The 2018 Medical Deans of Australia and New Zealand (MDANZ) report indicated a further $3.9 \%$ drop in the number of physician-researchers between 2013 and $2017 .^{26}$ Comparatively, of the 1346 registered doctors who selfreported as physician-researchers in 2017, 59\% were males and $39 \%$ were 55 years and above. ${ }^{26}$

Decline in the number of HP researchers has largely been attributed to significant factors including lack of dedicated research time, research expertise, awareness and skills. $^{10,27}$ Additionally, there has been lack of effective succession planning. ${ }^{12}$ Furthermore, younger generations of HP graduates, particularly females, are wanting more work-life balance; and this generates situations where undertaking research competes with other goals, values and career pathways. ${ }^{3,7,28}$ Reduced accessibility to research positions, particularly in rural areas has also been highlighted as a major challenge. ${ }^{29}$ Building the capacity of HPs to undertake research is considered to be an international priority in view of the increasing predominance of chronic diseases and aging world populations. ${ }^{30}$ Health organisations with strong research culture have been associated with greater service efficiencies and reduced patient mortality and morbidity, indicating that involvement in research extends beyond individual HPs' professional development. $^{31}$

Motivation to undertake or stay in HMR is a key factor in addressing the shortage of HP researchers currently being experienced. ${ }^{32}$ Motivation has largely been attributed to the opportunities and barriers HPs have experienced or expect to experience in their research journey. ${ }^{32}$ However, the number of HPs engaging in research has still not improved. Applying a theoretically informed approach to examining existing literature findings can point the way to more effective strategies to motivate HPs to do research. The Expectancy-Value-Cost (EVC) motivation theory postulates that achievement-related choices are motivated by a combination of people's expectations for success and subjective task value in particular domains. ${ }^{33,34}$ For example, individuals are more likely to pursue an activity if they expect to do well and value the activity. The model further differentiates task value into three components: attainment value (ie, importance of doing well), intrinsic value (ie, personal enjoyment) and utility value (ie, perceived usefulness for future goals). However, motivation can be limited by potential barriers which are referred to as cost (ie, competition with other goals). According to the EVC model, expectations for success and task value are shaped by a combination of factors. These include individual characteristics (abilities, previous experiences, goals, self-concepts, beliefs, expectations, interpretations) and environmental influences (cultural milieu, socializers' beliefs, and behaviours). ${ }^{35}$

A recurrent theme in the literature is that motivation to undertake research has largely been extrinsic, that is, to improve $\mathrm{CVs}^{36}{ }^{36}$ career progression ${ }^{37}$ or for academic improvement. This indicates a need for further exploration into the underlying concepts of motivational theory and its relevance to research uptake and retention by HPs. It is not surprising, therefore, that motivation is increasingly becoming a major area of interest within the field of HPs' education ${ }^{38}$ and health research orientation, ${ }^{39}$ with a focus on Self-Determination Theory (SDT) $)^{40,41}$ which has special implications for HMR. Evolving from research 
on intrinsic and extrinsic motivations, SDT is a macro theory of human motivation that has been successfully applied to healthcare education and HMR. ${ }^{42,43}$ The focus of SDT is not on how motivation can be controlled from without, but instead on how motivation is functionally designed and experienced from within. ${ }^{41}$ SDT relates to three basic psychological needs: (1) Competence: People need to gain mastery of tasks and learn different skills. When people feel that they have the skills needed for success, they are more likely to take actions that will help them achieve their goals. (2) Connection or Relatedness: People need to experience a sense of belonging and attachment to other people. (3) Autonomy: People need to feel in control of their own behaviours and goals. This sense of being able to take direct action that will result in real change plays a major part in helping people feel self-determined. ${ }^{44}$

Rethinking HPs' motivation to engage in research, now has immediate and wider implications for all HPs whether medical, nursing and midwifery or allied health. ${ }^{6}$ The decline in number of HP researchers comes at a critical time when medical innovations are urgently needed to combat the current global COVID-19 pandemic, other communicable diseases and the aging population crisis. ${ }^{2,18}$ The threat to individual and societal health and economic welfare requires a holistic approach to HP engagement with research and research training to ensure long-term outcomes for survival of world populations. ${ }^{2}$ Research can no longer be restricted to an elite and specialized few, it needs to be appreciated as a fundamental activity for most, if not all HPs. To foster HP engagement with research, it is important to gain deep insight and understanding of what motivates or discourages them from taking up or continuing with research along the career pipeline. Hence this systematic review utilised two theoretical frameworks $\left(\mathrm{EVC}^{33,34}\right.$ and $\left.\mathrm{SDT}^{40,41}\right)$ to (1) examine the facilitators and barriers to health professionals' motivation to undertake research and (2) identify current research gaps.

\section{Methods}

The systematic review was conducted and reported in accordance with the PRISMA (Preferred Reporting Items for Systematic Reviews and Meta-Analyses) Statement.

\section{Inclusion and Exclusion Criteria}

For the purpose of this review, the term HP researcher is defined as a medical graduate, nurse, midwife or AHP who works both clinically and in research - often varying the fractions throughout their career. The study population consisted of all HPs: AHPs, Medical, Nursing and Midwifery in hospital/research centres. Peer-reviewed articles written in English were considered if they related to HPs' motivation, attitudes, and perceptions about undertaking research. There was no restriction on study design. Articles were excluded if they did not meet the inclusion criteria and/or they were review papers.

\section{Search Strategy}

Seven electronic databases comprising, CINAHL Complete, Informit, Medline Ovid, Medline (PubMed), Scopus, Web of Science and Google Scholar were searched. Peer reviewed primary articles, written in English and published between 2011 and 2021 (a decade of literature) were included in this review to reflect the current level of activity in the topic area.

Search terms used were research, health professionals (including physicians, AHPs, nurses, midwives), research, and motivation. The terms research capacity, attitudes and barriers were purposefully excluded as they would have limited a full exploration of the topic. The comprehensive search strategy used for this review is presented in Appendix 1. Reference lists from previous reviews and included studies were also screened for additional relevant articles.

\section{Study Selection}

All the identified articles were imported into Endnote X9 software (Clarivate, Australia), then titles and abstracts were screened. Two authors (LMDA and BSMA) independently screened the titles and abstracts of the retrieved articles and excluded those that did not meet the inclusion criteria. Subsequently, full-text articles categorised as potentially eligible for inclusion were screened and disagreements were resolved in a consensus meeting.

\section{Data Synthesis and Analysis}

Meta-analysis was not possible, due to the heterogeneous nature of the included articles. A data extraction form was developed and used to collect relevant information from all the included studies. Descriptive data including author, study year, title, country of study, research/study focus, setting - urban/rural/remote, study design, type of participants, participant numbers, gender and mean age were extracted from each of the selected studies. Elements of the Self-Determination Theory $(\mathrm{SDT})^{43}$ and the Expectancy-Value-Cost Model of Motivation (EVC) ${ }^{46}$ 
were adopted to facilitate extraction of the key determinant factors to research motivation. The identified barriers and facilitators of HPs' motivation to undertake research, as reported in each reviewed article were independently extracted and categorised by two authors (LMDA and BSMA). Conceptual content analysis ${ }^{47,48}$ was used to extract and systematically code the factors as determined by the tenets of the EVC and SDT frameworks. Rules for translation of text into codes were developed by the researchers. Coding of pre-defined concepts/sets of categories was done manually and analysis of results involved quantification of coded concepts for frequency of occurrence and determination of relationships, trends and patterns. ${ }^{48}$

Three major factors were considered namely: Research Capacity which relates to expectancy and competence; Attitude which relates to value and connection; and Barriers which relate to cost and autonomy. Research capacity was coded based on explicit/implicit statements within each reviewed article about participants' perceived levels of confidence/ competence to participate in research. Participants' attitude to research was underpinned by the type of value they attributed to research - attainment, intrinsic and/or utility value, as well as the connection or relatedness they expressed towards research. Participants' attitude to research was categorised into three groups based on the frequency with which values and connections held by the study participants were openly stated or inferred. Attitude to research was coded as "very positive" if all three value types were established in a study, "positive" if only one and "negative/fear of research" if no value or connection to research was indicated. For autonomy/ cost, reported barriers in all studies were listed and grouped into categories, number of categorised barriers in each study were then quantified. LMDA and BSMA independently extracted and categorised all factors and subsequently met to check for consistency. All discrepancies were resolved through discussion.

For the purpose of this review, research capacity is defined as the ability to engage in, perform or carry out quality research. ${ }^{49}$ The expectancy and competence of individuals to carry out research activities underpins research capacity and was viewed through the EVC (expectancy) and SDT (competence) frameworks. While it is postulated that there are two types of expectancies: ability beliefs that comprise of current/immediate beliefs about being able to complete a task and expectancy beliefs that reflect being able to do the task in the future, most investigations collapse measures of ability and expectancy beliefs into a general expectancy scale. ${ }^{46}$

Attitude to undertaking research was viewed through the EVC (value) and SDT (connection) frameworks. Value is differentiated into three components: value of attainment is espoused in meeting a personal need; intrinsic value is gained through personal enjoyment or satisfaction and utility value is perceived usefulness for future goals and may be predictive of current and future interest. ${ }^{46}$ Connection or relatedness is where people need to experience a sense of belonging and attachment to other people. $^{44}$

Barriers to undertaking research was also viewed through the EVC (Cost) and SDT (autonomy) frameworks where the perceived cost of undertaking research competes with other goals, ${ }^{44}$ and autonomy is seen as the need to feel in control of one's own behaviours and goals without undue external influences. ${ }^{44}$ Cost and autonomy are largely seen as influences external to the individual although they may be encountered at the individual, organisational and/or system level. ${ }^{43,46}$

\section{Quality Assessment of Reviewed Articles}

The Quality Assessment Tool for Studies with Diverse Designs (QATSDD) was used to assess the methodological consistency and quality of the included studies. ${ }^{50}$ This tool contains 16 items and is used for examining studies with different research designs. Each of the included studies was graded on a scale of 0 to 3 for each criterion, with 0 $=$ not at all, $1=$ very slightly, $2=$ moderately and $3=$ complete. To assess the methodological quality of each of the included studies, the criteria scores were summed and expressed as a percentage of the maximum possible score. The percentage scores were classified into low $(<50 \%)$, medium $(50-80 \%)$ or high $(>80 \%)$ quality evidence for easy identification. The QATSDD criteria included: (1) theoretical framework; (2) aims/objectives; (3) description of research setting; (4) sample size; (5) representative sample of target group; (6) procedure for data collection; (7) rationale for choice of data collection tool(s); (8) detailed recruitment data; (9) assessment of reliability and validity of measurement tool(s) (Quantitative only); (10) fit between research question and method of data collection (Quantitative only); (11) fit between research question and data collection method (Qualitative only); (12) fit between research question and method of analysis; (13) good justification for analytical method selected; (14) reliability of analytical process (Qualitative only); (15) 
evidence of user involvement in design; (16) strengths and limitations. ${ }^{50}$

\section{Results}

\section{Included Studies}

Four thousand and twenty four (4024) articles were identified from all searched databases. Ten (10) additional articles were identified through hand searching. After screening the titles and abstracts of the identified articles and reviewing 228 full texts, 46 met the inclusion criteria for this review as shown in Figure 1.

\section{Assessment of Methodological Quality}

Table 1 portrays the QATSDD assessment with scores ranging from $33 \%$ to $90 \%$. The aims and objectives, description of the research setting as well as the fit between research question and data collection method were well addressed in most studies. Strengths and limitations of the studies were also generally well addressed by most studies. Nonetheless, good justification for analytical method selected was overlooked in 14 studies and only $19(41.3 \%)$ studies had evidence of user involvement in the design. Overall, 10 studies (22\%) were rated as high quality because they were judged to be explicit in their methodology and mostly utilised theoretical frameworks. Thirty-five (76\%) were medium quality studies and some of the weaknesses identified from these studies included: lack of theoretical framework, inadequate sample sizes and poor reliability. One study ${ }^{51}$ met only few quality criteria, had low rating (33\%) and therefore was removed from the review.

\section{Study Characteristics}

A summary of the characteristics of the included 45 studies is presented in Table 2. The total number of participants was 11,438 and participant numbers per study ranged from 15 to 2052 . Of the 33 studies that included

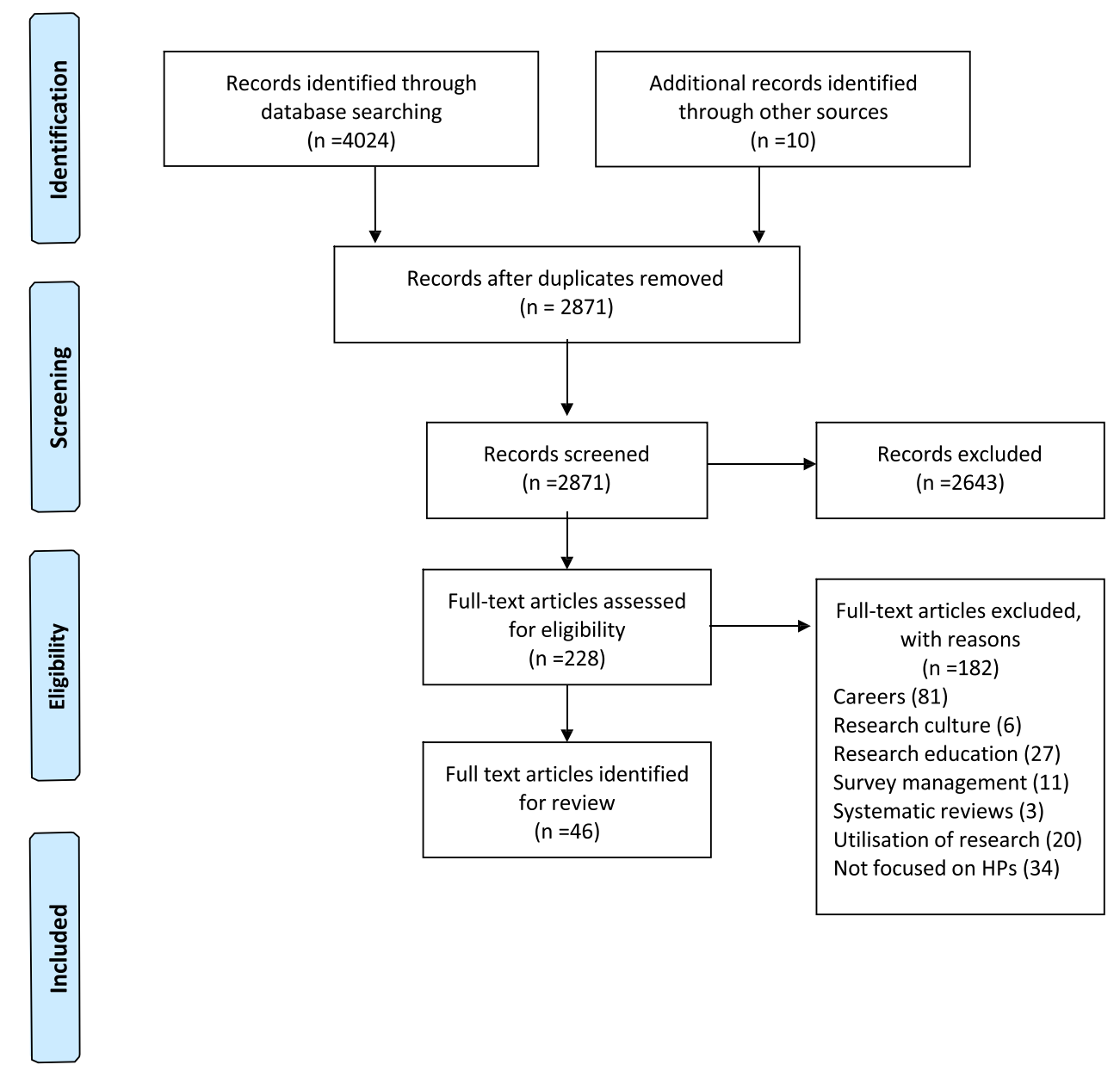

Figure I Flow chart of the study selection protocol. PRISMA figure adapted from Moher D, Liberati A, Tetzlaff J, Altman DG, The PRISMA Group (2009). Preferred Reporting Items for Systematic Reviews and Meta-Analyses: The PRISMA Statement. PLoS Med. 6(7):el000097. Creative Commons ${ }^{45}$. 
Table I Quality Assessment of the Included Studies

\begin{tabular}{|c|c|c|c|c|c|c|c|c|c|c|c|c|c|c|c|c|c|c|c|}
\hline QATSDD Criteria & 1 & 2 & 3 & 4 & 5 & 6 & 7 & 8 & 9 & 10 & 11 & 12 & 13 & 14 & 15 & 16 & Total Score & $\%$ of Total Score & Grade \\
\hline Akerjordet, Lode, and Severinsson $2012^{83}$ & 0 & 3 & 2 & 1 & 3 & 1 & 0 & 3 & 3 & 2 & N/A & 3 & 0 & N/A & 0 & 3 & $24 / 42$ & 57 & Good \\
\hline Albert et al $2016^{67}$ & 0 & 3 & 3 & 3 & 3 & 3 & 3 & 2 & 3 & 3 & $\mathrm{~N} / \mathrm{A}$ & 3 & 1 & N/A & 0 & 3 & $33 / 42$ & 79 & Good \\
\hline Alison, Zafiropoulos, and Heard $2017^{64}$ & 0 & 3 & 3 & 3 & 3 & 3 & 3 & 3 & 3 & 3 & $\mathrm{~N} / \mathrm{A}$ & 3 & 3 & $\mathrm{~N} / \mathrm{A}$ & 0 & 3 & $36 / 42$ & 86 & Excellent \\
\hline Bench, Dowie-Baker, and Fish $2019^{74}$ & 0 & 3 & 3 & 1 & 2 & 3 & 0 & 3 & 1 & 3 & 3 & 3 & 0 & 3 & 2 & 2 & $32 / 48$ & 67 & Good \\
\hline Berthelsen and Holge-Hazelton $2015^{84}$ & 0 & 3 & 3 & 2 & 2 & 3 & 2 & 3 & 3 & 3 & N/A & 2 & 1 & N/A & 0 & 2 & $29 / 42$ & 69 & Good \\
\hline Borkowski, McKinstry, and Cotchett $2017^{52}$ & 0 & 3 & 2 & 1 & 3 & 2 & 3 & 2 & I & 3 & N/A & 3 & 2 & N/A & 0 & 2 & $27 / 42$ & 64 & Good \\
\hline Chan et al $2011^{68}$ & 0 & 3 & 2 & 2 & 3 & 2 & 3 & 3 & 3 & 3 & N/A & 2 & 0 & N/A & 0 & 0 & $26 / 42$ & 62 & Good \\
\hline Choo, Muninathan, Pung, and Ramanathan $2017^{89}$ & 0 & 3 & 3 & 3 & 3 & 2 & 3 & 3 & 1 & 3 & $\mathrm{~N} / \mathrm{A}$ & 3 & 1 & $\mathrm{~N} / \mathrm{A}$ & 2 & 2 & $32 / 42$ & 76 & Good \\
\hline Cianciolo et al $2020^{69}$ & 3 & 3 & 3 & 1 & 1 & 3 & 2 & 2 & N/A & N/A & 3 & 3 & 2 & 3 & 2 & 3 & $34 / 42$ & 81 & Excellent \\
\hline Connolly, Allum, Shaw, Pattison, and Dark $2018^{75}$ & 3 & 3 & 3 & 2 & 3 & 3 & 3 & 2 & 1 & 3 & 3 & 2 & 3 & 3 & 2 & 3 & $42 / 48$ & 86 & Excellent \\
\hline Conradie, Duys, Forget, and Biccard $2018^{16}$ & 0 & 3 & 3 & 3 & 2 & 3 & 1 & 3 & 0 & 3 & 2 & 3 & 1 & 3 & 0 & 3 & $33 / 48$ & 69 & Good \\
\hline Dannapfel, Peolsson, and Nilsen $2013^{85}$ & 0 & 3 & 3 & 2 & 3 & 3 & 1 & 2 & N/A & N/A & 1 & 3 & 3 & 3 & 1 & 0 & $28 / 42$ & 67 & Good \\
\hline Dannapfel, Peolsson, Stahl, Oberg, and Nilsen $2014^{86}$ & 3 & 3 & 3 & 2 & 3 & 3 & 1 & 2 & $N / A$ & N/A & 2 & 3 & 3 & 3 & 1 & 3 & $35 / 42$ & 83 & Excellent \\
\hline Elphinston and Pager $2015^{53}$ & 0 & 3 & 3 & 2 & 1 & 3 & 1 & 2 & 3 & 3 & N/A & 3 & 0 & N/A & 0 & 3 & $27 / 42$ & 64 & Good \\
\hline Finch, Cornwell, Nalder, and Ward $2015^{54}$ & 0 & 3 & 3 & 3 & 3 & 3 & 2 & 2 & $N / A$ & N/A & 3 & 3 & 1 & 3 & 0 & 3 & $32 / 42$ & 76 & Good \\
\hline Harvey, Plummer, Nielsen, Adams, and Pain $2016^{55}$ & 0 & 3 & 3 & 3 & 3 & 2 & 0 & 2 & $N / A$ & N/A & 1 & 3 & 2 & 3 & 0 & 3 & $28 / 42$ & 67 & Good \\
\hline Hiscock et al $2014^{56}$ & 0 & 3 & 2 & 2 & 3 & 3 & 0 & 1 & 0 & 3 & $\mathrm{~N} / \mathrm{A}$ & 3 & 1 & $\mathrm{~N} / \mathrm{A}$ & 2 & 3 & $26 / 42$ & 62 & Good \\
\hline Ito-Ihara et al $2013^{91}$ & 0 & 3 & 3 & 2 & 3 & 2 & 2 & 3 & 0 & 3 & 2 & 3 & 1 & 3 & 0 & 3 & $33 / 48$ & 69 & Good \\
\hline Janssen, Hale, Mirfin-Veitch, and Harland $2016^{93}$ & 0 & 3 & 3 & 1 & 3 & 3 & 3 & 2 & 3 & 3 & 3 & 3 & 3 & 3 & 0 & 3 & $39 / 48$ & 81 & Excellent \\
\hline Jones, Griffith, Ubel, Stewart, and Jagsi $2016^{32}$ & 0 & 3 & 2 & 2 & 3 & 3 & 1 & 2 & 0 & 3 & 3 & 3 & 2 & 0 & 0 & 3 & $30 / 48$ & 63 & Good \\
\hline Lowrie et al $2015^{76}$ & 0 & 3 & 2 & 3 & 3 & 3 & 1 & 3 & $N / A$ & N/A & 3 & 3 & 3 & 3 & 2 & 3 & $35 / 42$ & 83 & Excellent \\
\hline Luckson, Duncan, Rajai, and Haigh $2018^{79}$ & 0 & 3 & 3 & 1 & 2 & 2 & 3 & 3 & I & 3 & 3 & 3 & 1 & 0 & 3 & 3 & $34 / 48$ & 71 & Good \\
\hline Mahmoud et al $2011^{87}$ & 0 & 3 & 3 & 2 & 2 & 2 & 0 & 2 & 0 & 3 & N/A & 3 & 1 & N/A & 2 & 2 & $25 / 42$ & 60 & Good \\
\hline Mansi, Karam, and Chaaban $2019^{70}$ & 0 & 3 & 3 & 2 & 2 & 2 & 0 & 2 & 0 & 2 & N/A & 3 & 0 & N/A & 0 & 3 & $22 / 42$ & 52 & Good \\
\hline Marshall et al $2016^{65}$ & 0 & 3 & 3 & 3 & 1 & 3 & 3 & 3 & 3 & 3 & 3 & 3 & 3 & 3 & 3 & 3 & $43 / 48$ & 90 & Excellent \\
\hline
\end{tabular}




\begin{tabular}{|c|c|c|c|c|c|c|c|c|c|c|c|c|c|c|c|c|c|c|c|}
\hline McDonald $2020^{92}$ & 0 & 3 & 3 & 2 & 2 & 3 & 0 & 3 & I & 3 & N/A & 3 & 0 & N/A & 2 & 3 & $28 / 42$ & 67 & Good \\
\hline McMaster, Jammali-Blasi, Andersson-Noorgard, Cooper, and Mclnnes $2013^{57}$ & 0 & 3 & 3 & 2 & 3 & 2 & 1 & 3 & । & 3 & N/A & 3 & 0 & N/A & 1 & 1 & $26 / 42$ & 62 & Good \\
\hline McNab, Berry, and Skapetis $2019^{58}$ & 0 & 3 & 3 & 3 & 2 & 2 & 0 & 3 & । & 2 & N/A & 3 & 3 & N/A & 2 & 3 & $30 / 42$ & 71 & Good \\
\hline Mills et al $2019^{3}$ & 0 & 3 & 3 & 3 & 3 & 3 & 0 & 2 & 0 & 3 & N/A & 3 & 0 & N/A & 0 & 3 & $26 / 42$ & 62 & Good \\
\hline Oliver-Baxter, Brown, and McIntyre $2017^{59}$ & 0 & 3 & 3 & 2 & 3 & 3 & 0 & 3 & I & 3 & N/A & 2 & 0 & N/A & 0 & 3 & $26 / 42$ & 62 & Good \\
\hline Pager, Holden, and Golenko $2012^{60}$ & 0 & 3 & 3 & 2 & 2 & 3 & 2 & 2 & I & 2 & 2 & I & 0 & 1 & 0 & 3 & $27 / 48$ & 56 & Good \\
\hline Paget, Lilischkis, Morrow, and Caldwell $2014^{66}$ & 0 & 3 & 2 & 3 & 1 & 3 & 2 & 3 & 0 & 3 & N/A & 2 & 0 & N/A & 3 & 0 & $25 / 42$ & 60 & Good \\
\hline Pain, Petersen, and Fernando $2018^{61}$ & 0 & 3 & 3 & 2 & 2 & 2 & 0 & 3 & 0 & 3 & N/A & 2 & 1 & N/A & 0 & 2 & $23 / 42$ & 55 & Good \\
\hline Sarwar et al $2018^{80}$ & 0 & 3 & 3 & 3 & 3 & 2 & 0 & 3 & 3 & 3 & N/A & 3 & 0 & N/A & 2 & 2 & $30 / 42$ & 71 & Good \\
\hline Scala, Patterson, Stavarski, and Mackay $2019^{71}$ & 2 & 3 & 3 & 3 & 3 & 3 & 0 & 2 & N/A & N/A & 3 & 3 & 0 & 3 & 0 & 2 & $30 / 42$ & 71 & Good \\
\hline Siedlecki and Albert $2016^{72}$ & 3 & 3 & 3 & 2 & 2 & 2 & 0 & 3 & N/A & N/A & 2 & 2 & 1 & 3 & 0 & 2 & $28 / 42$ & 67 & Good \\
\hline Silberman et al $2012^{73}$ & 0 & 3 & 3 & 2 & 3 & 2 & 0 & 3 & 0 & 3 & N/A & 3 & 0 & N/A & 0 & 3 & $25 / 42$ & 60 & Good \\
\hline Snelgrove and James $2011^{77}$ & 0 & 3 & 3 & 1 & 1 & 2 & 0 & 3 & 0 & 3 & 3 & 2 & 1 & 3 & 0 & 1 & $26 / 42$ & 62 & Good \\
\hline Stewart et al $2015^{81}$ & 0 & 3 & 3 & 2 & 2 & 3 & I & 2 & 3 & 3 & N/A & 3 & 3 & N/A & 2 & 2 & $32 / 42$ & 76 & Good \\
\hline Stewart et al $2019^{78}$ & 3 & 3 & 3 & 1 & 3 & 3 & 2 & 2 & 3 & 3 & N/A & 3 & 2 & N/A & 0 & 3 & $34 / 42$ & 81 & Excellent \\
\hline Sultana, Al Jeraisy, Al Ammari, Patel, and Zaidi $2016^{82}$ & 1 & 3 & 3 & 2 & 3 & 3 & 1 & 3 & 3 & 3 & N/A & 3 & 1 & N/A & 2 & 3 & $34 / 42$ & 81 & Excellent \\
\hline Torres et al $2017^{90}$ & 0 & 3 & 3 & 2 & 2 & 3 & 1 & 3 & 3 & 3 & N/A & 3 & 1 & N/A & 2 & 2 & $31 / 42$ & 74 & Good \\
\hline van Hoving and Brysiewicz 201788 & 0 & 3 & 3 & 1 & 3 & 3 & I & 3 & 0 & 3 & N/A & 3 & 1 & N/A & 0 & 3 & $27 / 42$ & 64 & Good \\
\hline Wenke, Mickan, and Bisset $2017^{62}$ & 0 & 3 & 3 & 1 & 2 & 3 & 3 & 3 & 0 & 3 & N/A & 3 & 2 & N/A & 0 & 3 & $29 / 42$ & 69 & Good \\
\hline Wenke, Noble, Weir, and Mickan $2020^{63}$ & 3 & 3 & 3 & 3 & 2 & 3 & 2 & 3 & N/A & N/A & 3 & 3 & 3 & 3 & 0 & 2 & $36 / 42$ & 86 & Excellent \\
\hline White $2013^{51}$ & 1 & 3 & 2 & 1 & 1 & 0 & 1 & 2 & I & 2 & N/A & I & 1 & N/A & 0 & 0 & $16 / 48$ & 33 & Low \\
\hline
\end{tabular}

Notes: The QATSDD criteria included: (I) theoretical framework; (2) aims/objectives; (3) description of research setting; (4) sample size; (5) representative sample of target group; (6) procedure for data collection; (7) rationale for choice of data collection tool(s); (8) detailed recruitment data; (9) assessment of reliability and validity of measurement tool(s) (quantitative only); (I0) fit between research question and method of data collection (quantitative only); ( II) fit between research question and data collection method (qualitative only); (12) fit between research question and method of analysis; (13) good justification for analytical method selected; (14) reliability of analytical process (qualitative only); (15) evidence of user involvement in design; (16) strengths and limitations. 
Table 2 Study Characteristics and Participant Demographics for Reviewed Articles

\begin{tabular}{|c|c|c|c|c|c|c|}
\hline Author and Year & Title & Country & Setting & $\begin{array}{l}\text { Study } \\
\text { Design }\end{array}$ & $\begin{array}{l}\text { Type of } \\
\text { Participants }\end{array}$ & $\begin{array}{l}\text { Participants (No., Gender, } \\
\text { Mean Age [Yrs.]) Response } \\
\text { Rate }\end{array}$ \\
\hline $\begin{array}{l}\text { Akerjordet, Lode, and } \\
\text { Severinsson } 2012^{83}\end{array}$ & $\begin{array}{l}\text { Clinical nurses' attitudes towards research, management and } \\
\text { organisational resources in a university hospital: part I }\end{array}$ & Norway & $\begin{array}{l}\text { Not } \\
\text { stated }\end{array}$ & Quantitative & Nurses & $\begin{array}{l}\mathrm{N}=364 ; \text { Females }(95 \%, \mathrm{n}=347) ; \\
\text { Age: }(41.2 \pm 11.52) \text { RR } 61 \%\end{array}$ \\
\hline Albert et al $2016^{67}$ & $\begin{array}{l}\text { Clinical nurse specialist roles in conducting research: Changes over } 3 \\
\text { years }\end{array}$ & USA & Urban & Quantitative & Nurses & $\begin{array}{l}N=2052 ; \text { Females }(95.9 \%, n \\
=\text { I782); Age: }(50.3 \pm 9.3) \text { RR } 25 \%\end{array}$ \\
\hline $\begin{array}{l}\text { Alison, Zafiropoulos, and } \\
\text { Heard } 2017^{64}\end{array}$ & $\begin{array}{l}\text { Key factors influencing allied health research capacity in a large } \\
\text { Australian metropolitan health district }\end{array}$ & Australia & Urban & Quantitative & Allied Health & $\begin{array}{l}N=278 ; \text { Females**; Age: }<25- \\
>60 y r s: \text { RR } 54 \%\end{array}$ \\
\hline $\begin{array}{l}\text { Bench, Dowie-Baker, and } \\
\text { Fish } 2019^{74}\end{array}$ & $\begin{array}{l}\text { Orthopaedic nurses' engagement in clinical research; an exploration of } \\
\text { ideas, facilitators, and challenges }\end{array}$ & UK & $\begin{array}{l}\text { Not } \\
\text { stated }\end{array}$ & $\begin{array}{l}\text { Mixed } \\
\text { methods }\end{array}$ & Nurses & $\begin{array}{l}N=75 ; \text { Females }(75 \%, n=56) \\
\text { Age: }(>40=56 \%) \text { RR } 20 \%\end{array}$ \\
\hline $\begin{array}{l}\text { Berthelsen and Holge- } \\
\text { Hazelton } 2015^{84}\end{array}$ & $\begin{array}{l}\text { Orthopaedic nurses' attitudes towards clinical nursing research - A } \\
\text { cross-sectional survey }\end{array}$ & Denmark & Regional & Quantitative & Nurses & $\begin{array}{l}N=43 ; \text { Females }(97.8 \%, n=42) ; \\
\text { Age: }(>40=62.7 \%) \text { RR } 49.4 \%\end{array}$ \\
\hline $\begin{array}{l}\text { Borkowski, McKinstry, and } \\
\text { Cotchett } 2017^{52}\end{array}$ & Research culture in a regional allied health setting & Australia & Regional & Quantitative & Allied Health & $\begin{array}{l}N=136 ; \text { Females } * * ; \text { Age**: RR } \\
46 \%\end{array}$ \\
\hline Chan et al $2011^{68}$ & $\begin{array}{l}\text { Barriers and perceived needs for understanding and using research } \\
\text { among emergency nurses }\end{array}$ & USA & $\begin{array}{l}\text { Not } \\
\text { stated }\end{array}$ & Quantitative & Nurses & $\begin{array}{l}N=978 ; \text { Females*; Age**: RR } \\
3.6 \%\end{array}$ \\
\hline $\begin{array}{l}\text { Choo, Muninathan, Pung, and } \\
\text { Ramanathan } 2017^{89}\end{array}$ & $\begin{array}{l}\text { Attitudes, barriers, and facilitators to the conduct of research in } \\
\text { government hospitals: a cross-sectional study among specialists in } \\
\text { government hospitals, northern states of Malaysia }\end{array}$ & Malaysia & $\begin{array}{l}\text { Not } \\
\text { stated }\end{array}$ & Quantitative & Physicians & $\begin{array}{l}N=467 ; \text { Females }(49.9 \%, n \\
=233) ; \text { Age: } 30-44 y r s n=340 \\
\text { (72.8\%) RR } 63.7 \%\end{array}$ \\
\hline Cianciolo et al $2020^{69}$ & $\begin{array}{l}\text { Physician-scientist or basic scientist? Exploring the nature of clinicians' } \\
\text { research engagement }\end{array}$ & $\begin{array}{l}\text { USA and } \\
\text { Pakistan }\end{array}$ & $\begin{array}{l}\text { Urban } \\
\text { and rural }\end{array}$ & Qualitative & Physicians & $\begin{array}{l}N=36 ; \text { Females }(39 \%, n=14) \\
\text { Age: }(34.5+9.5)\end{array}$ \\
\hline $\begin{array}{l}\text { Connolly, Allum, Shaw, } \\
\text { Pattison, and Dark } 2018^{75}\end{array}$ & $\begin{array}{l}\text { Characterising the research profile of the critical care physiotherapy } \\
\text { workforce and engagement with critical care research: a UK national } \\
\text { survey }\end{array}$ & UK & $\begin{array}{l}\text { Not } \\
\text { stated }\end{array}$ & Quantitative & Physiotherapists & $\mathrm{N}=268 ;$ Females $* *$ Age $*$ RR $* *$ \\
\hline $\begin{array}{l}\text { Conradie, Duys, Forget, and } \\
\text { Biccard } 2018^{16}\end{array}$ & $\begin{array}{l}\text { Barriers to clinical research in Africa: a quantitative and qualitative } \\
\text { survey of clinical researchers in } 27 \text { African countries }\end{array}$ & Africa & $\begin{array}{l}\text { Not } \\
\text { stated }\end{array}$ & $\begin{array}{l}\text { Mixed } \\
\text { methods }\end{array}$ & Physicians & $\begin{array}{l}N=134 ; \text { Females**; Age**; } \\
\text { RR }=32 \%\end{array}$ \\
\hline $\begin{array}{l}\text { Dannapfel, Peolsson, and } \\
\text { Nilsen } 2013^{85}\end{array}$ & $\begin{array}{l}\text { What supports physiotherapists' use of research in clinical practice? A } \\
\text { qualitative study in Sweden }\end{array}$ & Sweden & $\begin{array}{l}\text { Urban } \\
\text { and rural }\end{array}$ & Qualitative & Physiotherapists & $\begin{array}{l}N=45 ; \text { Females }(75 \%, n=33) \\
\text { Age: }(4 I+\mid I) R R^{* *}\end{array}$ \\
\hline $\begin{array}{l}\text { Dannapfel, Peolsson, Stahl, } \\
\text { Oberg, and Nilsen } 2014^{86}\end{array}$ & $\begin{array}{l}\text { Applying self-determination theory for improved understanding of } \\
\text { physiotherapists' rationale for using research in clinical practice: a } \\
\text { qualitative study in Sweden }\end{array}$ & Sweden & $\begin{array}{l}\text { Urban } \\
\text { and rural }\end{array}$ & Qualitative & Physiotherapists & $\begin{array}{l}N=45 ; \text { Females }(75 \%, n=33) \\
\text { Age: }(4 I .1 I+5) R R=R R^{* *}\end{array}$ \\
\hline
\end{tabular}




\begin{tabular}{|c|c|c|c|c|c|c|}
\hline Elphinston and Pager 2015 $5^{53}$ & Untapped potential: Psychologists leading research in clinical practice & Australia & Urban & Quantitative & Psychologists & $\begin{array}{l}\mathrm{N}=60 ; \text { Females }(77 \%, \mathrm{n}=46) \\
\text { Age**: RR mean } 26.1 \text { across } 3 \\
\text { time points }\end{array}$ \\
\hline $\begin{array}{l}\text { Finch, Cornwell, Nalder, and } \\
\text { Ward } 2015^{54}\end{array}$ & $\begin{array}{l}\text { Uncovering motivators and stumbling blocks: Exploring the clinical } \\
\text { research experiences of speech-language pathologists }\end{array}$ & Australia & $\begin{array}{l}\text { Urban } \\
\text { and rural }\end{array}$ & Qualitative & $\begin{array}{l}\text { Speech language } \\
\text { pathologists }\end{array}$ & $\begin{array}{l}N=21 ; \text { Females }(100 \%, n=2 I) \\
\text { Age**: RR** }\end{array}$ \\
\hline $\begin{array}{l}\text { Harvey, Plummer, Nielsen, } \\
\text { Adams, and Pain } 2016^{55}\end{array}$ & Becoming a clinician researcher in allied health & Australia & Regional & Qualitative & Allied Health & $\begin{array}{l}N=15 ; \text { Females }(87 \%, n=13) \\
\text { Age**: RR** }\end{array}$ \\
\hline Hiscock et al $2014^{56}$ & $\begin{array}{l}\text { Clinical research potential in Victorian hospitals: the Victorian clinician } \\
\text { researcher needs analysis survey }\end{array}$ & Australia & $\begin{array}{l}\text { Urban } \\
\text { and rural } \\
\text { and } \\
\text { remote }\end{array}$ & Quantitative & $\begin{array}{l}\text { Allied Health } \\
\text { Nurses } \\
\text { Physicians }\end{array}$ & $\begin{array}{l}N=1027 ; \text { Females }(67 \%, n=688) ; \\
\text { Age**: RR** }\end{array}$ \\
\hline Ito-Ihara et al $2013^{91}$ & $\begin{array}{l}\text { An international survey of physicians regarding clinical trials: a } \\
\text { comparison between Kyoto University Hospital (KUPH) and Seoul } \\
\text { National University Hospital (SNUH) }\end{array}$ & $\begin{array}{l}\text { Japan and } \\
\text { South } \\
\text { Korea }\end{array}$ & Urban & Quantitative & Physicians & $\begin{array}{l}\text { KUPH N = 30I; Females }(17 \%, n \\
=50) ; \text { Age } \leq 29-\geq 50: \text { RR } 64 \% \\
\text { SNUH N = 398; Females } 37 \% \text { n = } \\
\text { I47: Age } \leq 29->50: \text { RR } 45 \%\end{array}$ \\
\hline $\begin{array}{l}\text { Janssen, Hale, Mirfin-Veitch, } \\
\text { and Harland } 2016^{93}\end{array}$ & $\begin{array}{l}\text { Perceptions of physiotherapists towards research: a mixed methods } \\
\text { study }\end{array}$ & $\begin{array}{l}\text { New } \\
\text { Zealand }\end{array}$ & $\begin{array}{l}\text { Not } \\
\text { stated }\end{array}$ & $\begin{array}{l}\text { Mixed } \\
\text { methods }\end{array}$ & Physiotherapists & $\begin{array}{l}N=25 ; \text { Females }(84 \%, n=2 I) \\
\text { Age: }(38.1 \mathrm{I}) ; R^{* *}\end{array}$ \\
\hline $\begin{array}{l}\text { Jones, Griffith, Ubel, Stewart, } \\
\text { and Jagsi } 2016^{32}\end{array}$ & $\begin{array}{l}\text { A mixed-methods investigation of the motivations, goals, and } \\
\text { aspirations of male and female academic medical faculty }\end{array}$ & USA & $\begin{array}{l}\text { Not } \\
\text { stated }\end{array}$ & $\begin{array}{l}\text { Mixed } \\
\text { methods }\end{array}$ & Physicians & $\begin{array}{l}N=1275 ; \text { Females }(45.6 \%, n \\
=582) ; \text { Age** RR }=74.6 \%\end{array}$ \\
\hline Lowrie et al $2015^{76}$ & $\begin{array}{l}\text { Research is 'a step into the unknown': an exploration of pharmacists' } \\
\text { perceptions of factors impacting on research participation in the NHS }\end{array}$ & UK & $\begin{array}{l}\text { Urban } \\
\text { and rural }\end{array}$ & Qualitative & Pharmacists & $\begin{array}{l}\mathrm{N}=54 ; \text { Females }(68 \%, \mathrm{n}=37) \\
\text { Age** } \mathrm{RR}^{* *}\end{array}$ \\
\hline $\begin{array}{l}\text { Luckson, Duncan, Rajai, and } \\
\text { Haigh } 2018^{79}\end{array}$ & $\begin{array}{l}\text { Exploring the research culture of nurses and allied health professionals } \\
\text { (AHPs) in a research-focused and a non-research-focused healthcare } \\
\text { organisation in the UK }\end{array}$ & UK & Urban & $\begin{array}{l}\text { Mixed } \\
\text { methods }\end{array}$ & $\begin{array}{l}\text { Allied Health } \\
\text { Nurses }\end{array}$ & $\begin{array}{l}N=224: \text { Females }(87 \%, n=194) ; \\
\text { Age** RR }=24 \%\end{array}$ \\
\hline Mahmoud et al $2011^{87}$ & $\begin{array}{l}\text { Survey of medical specialists on their attitudes to and resources for } \\
\text { health research in Nigeria }\end{array}$ & Nigeria & $\begin{array}{l}\text { Not } \\
\text { stated }\end{array}$ & Quantitative & Physicians & $\begin{array}{l}N=5 I ; \text { Females }(22 \%, n=I I) \\
\text { Age**: }(45.3+7.23) R R=63.3 \%\end{array}$ \\
\hline $\begin{array}{l}\text { Mansi, Karam, and Chaaban } \\
2019^{70}\end{array}$ & $\begin{array}{l}\text { Attitudes of residents and program directors towards research in } \\
\text { otolaryngology residency }\end{array}$ & USA & $\begin{array}{l}\text { Not } \\
\text { stated }\end{array}$ & Quantitative & Physicians & $\begin{array}{l}\mathrm{N}=209 \text { Residents } \mathrm{n}=178 \\
\text { Program directors } \mathrm{n}=31 \\
\text { Females**; Age**: RR** }\end{array}$ \\
\hline
\end{tabular}

(Continued) 
Table 2 (Continued).

\begin{tabular}{|c|c|c|c|c|c|c|}
\hline Author and Year & Title & Country & Setting & $\begin{array}{l}\text { Study } \\
\text { Design }\end{array}$ & $\begin{array}{l}\text { Type of } \\
\text { Participants }\end{array}$ & $\begin{array}{l}\text { Participants (No., Gender, } \\
\text { Mean Age [Yrs.]) Response } \\
\text { Rate }\end{array}$ \\
\hline Marshall et al $2016^{65}$ & Survey of research activity among multidisciplinary health professionals & Australia & Urban & $\begin{array}{l}\text { Mixed } \\
\text { Methods }\end{array}$ & $\begin{array}{l}\text { Allied Health } \\
\text { Nurses } \\
\text { Physicians }\end{array}$ & $\begin{array}{l}N=151 ; \text { Females }(56.2 \%, n=82) \\
\text { Age** } R R=2.5 \%\end{array}$ \\
\hline McDonald $2020^{92}$ & $\begin{array}{l}\text { Motivators and stressors for Canadian research coordinators in critical } \\
\text { care: The motivate survey }\end{array}$ & Canada & $\begin{array}{l}\text { Not } \\
\text { stated }\end{array}$ & Quantitative & $\begin{array}{l}\text { Allied Health } \\
\text { Nurses } \\
\text { Physicians }\end{array}$ & $\begin{array}{l}N=66 ; \text { Females**: Age**: } \\
\mathrm{RR}=78 \%\end{array}$ \\
\hline $\begin{array}{l}\text { McMaster, Jammali-Blasi, } \\
\text { Andersson-Noorgard, } \\
\text { Cooper, and Mclnnes } 2013^{57}\end{array}$ & $\begin{array}{l}\text { Research involvement, support needs, and factors affecting research } \\
\text { participation: A survey of Mental Health Consultation Liaison Nurses }\end{array}$ & Australia & $\begin{array}{l}\text { Not } \\
\text { stated }\end{array}$ & Quantitative & Nurses & $\begin{array}{l}N=31 ; \text { Females }(44 \%, n=14) \\
\text { Age: }(50-59 \text { yrs. }=50 \%) \text { RR }=94 \%\end{array}$ \\
\hline $\begin{array}{l}\text { McNab, Berry, and Skapetis } \\
2019^{58}\end{array}$ & $\begin{array}{l}\text { The potential of a lecture series in changing intent and experience } \\
\text { among health professionals to conduct research in a large hospital: a } \\
\text { retrospective pre-post design }\end{array}$ & Australia & Urban & Quantitative & $\begin{array}{l}\text { Allied Health } \\
\text { Nurses }\end{array}$ & $\begin{array}{l}N=49 ; \text { Females }(89.8 \%, n=44) \\
\text { Age: }(50-65 \text { years }=47.9 \%) \\
R R=38.9 \%\end{array}$ \\
\hline Mills et al $2019^{3}$ & $\begin{array}{l}\text { Attractions and barriers to Australian physician-researcher careers: } \\
\text { Physician-researcher influences }\end{array}$ & Australia & $\begin{array}{l}\text { Not } \\
\text { stated }\end{array}$ & Quantitative & Physicians & $\begin{array}{l}N=427 ; \text { Females }(44 \%, n=31) \\
\text { Age: }(38+13): R R^{* *}\end{array}$ \\
\hline $\begin{array}{l}\text { Oliver-Baxter, Brown, and } \\
\text { Mclntyre } 2017^{59}\end{array}$ & $\begin{array}{l}\text { Surviving or thriving in the primary health care research workforce: } \\
\text { the Australian experience }\end{array}$ & Australia & $\begin{array}{l}\text { Urban } \\
\text { and rural } \\
\text { and } \\
\text { remote }\end{array}$ & Quantitative & $\begin{array}{l}\text { Allied Health, } \\
\text { Nurses, } \\
\text { Physicians }\end{array}$ & $\begin{array}{l}N=37 ; \text { Females }(75.7 \%, n=28) \\
\text { Age: }(47.9+10.2): R R^{* *}\end{array}$ \\
\hline $\begin{array}{l}\text { Pager, Holden, and Golenko } \\
2012^{60}\end{array}$ & $\begin{array}{l}\text { Motivators, enablers, and barriers to building allied health research } \\
\text { capacity }\end{array}$ & Australia & $\begin{array}{l}\text { Not } \\
\text { stated }\end{array}$ & Quantitative & Allied Health & $\mathrm{N}=85 ;$ Females ${ }^{* *} ;$ Age ${ }^{* *}: \mathrm{RR} * *$ \\
\hline $\begin{array}{l}\text { Paget, Lilischkis, Morrow, } \\
\text { and Caldwell } 2014^{66}\end{array}$ & $\begin{array}{l}\text { Embedding research in clinical practice: differences in attitudes to } \\
\text { research participation among clinicians in a tertiary teaching hospital }\end{array}$ & Australia & Urban & Quantitative & $\begin{array}{l}\text { Allied Health, } \\
\text { Nurses, } \\
\text { Physicians }\end{array}$ & $\begin{array}{l}N=208 ; \text { Females }(76 \%, n=158) ; \\
\text { Age: }<30 \text { years }=20 \%, 30-50 \\
\text { years }=66 \%,>50 \text { years }=14 \% \text { : } \\
R R=17 \%\end{array}$ \\
\hline $\begin{array}{l}\text { Pain, Petersen, and Fernando } \\
2018^{61}\end{array}$ & $\begin{array}{l}\text { Building allied health research capacity at a regional Australian hospital: } \\
\text { A follow-up study }\end{array}$ & Australia & Regional & Quantitative & Allied Health & $\begin{array}{l}\text { 20II: } N=248 ; \text { Females }(76 \%, n \\
=188) ; \text { Age**: RR43\% } \\
\text { 20I5: } N=234 ; \text { Females }(76 \%, n \\
=178) ; \text { Age**: RR37\% }\end{array}$ \\
\hline
\end{tabular}




\begin{tabular}{|c|c|c|c|c|c|c|}
\hline Sarwar et al $2018^{80}$ & $\begin{array}{l}\text { Attitude, perception, willingness, motivation and barriers to practice- } \\
\text { based research: A cross-sectional survey of hospital pharmacists in } \\
\text { Lahore, Punjab, Pakistan }\end{array}$ & Pakistan & Urban & Quantitative & Pharmacists & $\begin{array}{l}\mathrm{N}=130 ; \text { Females }(42.3 \%, \mathrm{n}=55) \\
\text { Age: }<30 \text { yrs }(82.3 \%) \mathrm{RR}=92 \%\end{array}$ \\
\hline $\begin{array}{l}\text { Scala, Patterson, Stavarski, } \\
\text { and Mackay } 2019^{71}\end{array}$ & Engagement in research: A clinical nurse profile and motivating factors & USA & $\begin{array}{l}\text { Not } \\
\text { stated. }\end{array}$ & Qualitative & Nurses & $\begin{array}{l}\mathrm{N}=34 ; \text { Females }(91.2 \%, \mathrm{n}=31) \\
\text { Age**: }^{*} \mathrm{R}^{* *}\end{array}$ \\
\hline Siedlecki and Albert $2016^{72}$ & Research-active clinical nurses: against all odds & USA & $\begin{array}{l}\text { Not } \\
\text { stated }\end{array}$ & Qualitative & Nurses & $\begin{array}{l}N=26 ; \text { Females**; Age: }(50+7.7): \\
R R^{* *}\end{array}$ \\
\hline Silberman et al $2012^{73}$ & $\begin{array}{l}\text { Recruiting researchers in psychiatry: The influence of residency vs } \\
\text { early motivation }\end{array}$ & USA & Urban & Quantitative & Physicians & $\begin{array}{l}N=127 ; \text { Females }(51.6 \%, n \\
=65.5) ; \text { Age**: RR=67\% }\end{array}$ \\
\hline Snelgrove and James $2011^{77}$ & Graduate nurses' and midwives' perceptions of research & UK & $\begin{array}{l}\text { Not } \\
\text { stated }\end{array}$ & Qualitative & Nurses & $\begin{array}{l}N=58 ; \text { Females** Age**: } \\
R R=29 \%\end{array}$ \\
\hline Stewart et al $2015^{81}$ & $\begin{array}{l}\text { Building hospital pharmacy practice research capacity in Qatar: a cross- } \\
\text { sectional survey of hospital pharmacists }\end{array}$ & Qatar & Urban & Quantitative & Pharmacists & $\begin{array}{l}N=213 ; \text { Females }(47.9 \%, n \\
=102) ; \text { Age**: RR }=53.1 \%\end{array}$ \\
\hline Stewart et al $2019^{78}$ & $\begin{array}{l}\text { A theoretically informed survey of the views and experiences of } \\
\text { practicing pharmacists on research conduct, dissemination and } \\
\text { translation }\end{array}$ & UK & $\begin{array}{l}\text { Rural and } \\
\text { remote }\end{array}$ & Quantitative & Pharmacists & $\begin{array}{l}N=136 ; \text { Females }(76.5 \%, n \\
=104) \text {; Age: }(>4530.9 \%) R R= \\
19.4 \%\end{array}$ \\
\hline Torres et al $2017^{90}$ & $\begin{array}{l}\text { Assessment of research capacity among nursing faculty in a clinical } \\
\text { intensive university in the Philippines }\end{array}$ & Philippines & Urban & Quantitative & Nurses & $\begin{array}{l}N=66 ; \text { Females }(77 \%, n=51) \\
\text { Age**: RR } 80.49 \%\end{array}$ \\
\hline $\begin{array}{l}\text { van Hoving and Brysiewicz } \\
2017^{88}\end{array}$ & $\begin{array}{l}\text { African emergency care providers' attitudes and practices towards } \\
\text { research }\end{array}$ & Africa & $\begin{array}{l}\text { Not } \\
\text { stated }\end{array}$ & Quantitative & $\begin{array}{l}\text { Physicians, } \\
\text { Nurses }\end{array}$ & $\begin{array}{l}N=188 ; \text { Females }(27.4 \%, \mathrm{n}=46) ; \\
\text { Age: }(36.3+9.1) R R=34.8 \%\end{array}$ \\
\hline $\begin{array}{l}\text { Wenke, Mickan, and Bisset } \\
2017^{62}\end{array}$ & $\begin{array}{l}\text { A cross sectional observational study of research activity of allied } \\
\text { health teams: is there a link with self-reported success, motivators and } \\
\text { barriers to undertaking research? }\end{array}$ & Australia & Regional & Quantitative & Allied Health & $N=95 ;$ Females ${ }^{* *} ;$ Age**: RR ${ }^{* *}$ \\
\hline $\begin{array}{l}\text { Wenke, Noble, Weir, and } \\
\text { Mickan } 2020^{63}\end{array}$ & $\begin{array}{l}\text { What influences allied health clinician participation in research in the } \\
\text { public hospital setting: a qualitative theory-informed approach }\end{array}$ & Australia & Regional & Qualitative & Allied Health & $\begin{array}{l}N=21 ; \text { Females**; Age**: RR } \\
2.9 \%\end{array}$ \\
\hline
\end{tabular}

Note: **Values/categories not specified. 
both genders, 5620 (62.2\%) of the 9039 participants were females. Only 19 studies indicated participants' mean age which ranged from $34.5 \pm 9.5$ to $50 \pm 7.7$ years.

Sixteen (16) of the studies were conducted in Australia, ${ }^{3,52-66}$ eight from USA, ${ }^{32,67-73}$ six from UK, ${ }^{74-79}$ four from the Middle East, ${ }^{69,80-82}$ four from Europe ${ }^{83-86}$ three from Africa, ${ }^{16,87,88}$ two from South East Asia, ${ }^{89,90}$ one from Japan and South Korea ${ }^{91}$ and one each from Canada ${ }^{92}$ and New Zealand ${ }^{93}$ Study settings included 13 urban,$53,58,64-67,73,79-82,90,91$ six regional ${ }^{52,55,61-63,84}$ and five urban and rural settings. ${ }^{54,69,76,85,86}$ Two studies were conducted in all three settings (urban, rural and remote) ${ }^{56,59}$ while one was located in rural and remote settings. ${ }^{78}$ The setting type was not specified in 18 studies. The study designs were varied with 29 quantitative, 10 qualitative and six mixed methods studies.

Five studies focused on all $\mathrm{HPs}^{56,59,65,66,92}$ as a heterogeneous group, two on AHPs and nurses ${ }^{58,79}$ and one on nurses and physicians. ${ }^{88}$ Overall, 18 studies concentrated on AHPs with 7 of those studies considering them as a homogenous group, ${ }^{52,55,60-64}$ five studies were solely on pharmacists, ${ }^{76,78,80-82}$ four on physiotherapists ${ }^{75,85,86,93}$ and one each on psychologists ${ }^{53}$ and speech language pathologists. $^{54}$ Ten studies focused on nurses$57,67,68,71,72,74,77,83,84,90$ and nine on physicians. $^{3,16,32,69,70,73,87,89,91}$

While HPs' motivation to do research was investigated by all 45 reviewed studies, only eight studies utilised a theoretical framework or model in their investigation. These included Self-Determination Theory (SDT), ${ }^{86}$ Social Cognitive Career Theory (SCCCT) and Professional Identity Formation as an integrated framework, ${ }^{69}$ COM-B framework, ${ }^{75}$ Vroom's Expectancy Theory, ${ }^{71}$ Research-Active Nurse Model, ${ }^{72}$ Theoretical Domains Framework (TDF), ${ }^{78}$ Social Cognitive Theory, ${ }^{82}$ combination of TDF and COM-B. ${ }^{63}$

\section{Factors Influencing Motivation}

In relation to factors influencing motivation, all the studies in this review were appraised utilising the EVC and SDT frameworks. A summary of the findings is presented in Table 3.

\section{HPs' Research Capacity}

Research capacity was investigated in the studies in terms of competence/confidence and expectancy to do research. As shown in Table 3, over half 25 (56\%) of the reviewed studies identified their participants as competent to undertake research, while the participants in the remaining $20(44 \%)$ studies were identified as lacking confidence and requiring support to undertake research.

Of the 25 studies where participants were identified as competent, seven focused on physicians (medical doctors)., ${ }^{3,32,69,70,73,89,91}$ another seven on AHPs, ${ }^{52,55,60-64}$ four of which targeted pharmacists. ${ }^{78,80-82}$ Five studies focused on nurses, four on all HP groups and one each on nurse-physician group and nurse-AHP group. Most participants who felt competent perceived that they had the required abilities, skills, and knowledge to participate in research. For example, participants in one study reported high competence levels ranging from 3.14 to 4.06 on a 5point rating scale. ${ }^{90}$ About $60-90 \%$ of participants who were identified as competent reported having prior research experience, with $66-75 \%$ confirming that they had formal training during their undergraduate education.$3,58,65,66,70,75,80,82,88,90$ Between $20 \%$ and $65 \%$ of this group of participants indicated that they had either completed or were undertaking a postgraduate qualification which had enhanced their research capacity. ${ }^{59,60,71-}$ $73,75,77,78,81,82,88$

Eleven studies that targeted AHPs reported that the participants lacked competence/confidence to undertake research. Similar results were obtained for five studies focused on nurses, two on physicians and one each on all HP groups and nurse-AHP group. Common features for these studies were overwhelming poor research capacity, very little or no prior research training/experience, low research culture with other work roles taking priority and need for research support. In one study, participants indicated that they had never attended research training nor spent time on research and reported mean confidence level of $38 \%(\mathrm{SD} 27) .{ }^{93}$

Overall, the results show that HPs' confidence and expectancy to undertake research is largely dependent on research skills and experience gained through research training during their undergraduate/postgraduate education. The medical doctors were the most confident to undertake research as indicated in seven out of nine studies $(77.8 \%)$ compared to nurses in five out of $11(45.5 \%)$ studies; and AHPs in seven out of 18 (38.9\%) studies. This may be attributed to the reported early exposure to research training and research experience by the medical doctors in comparison to nurses and AHPs. These findings highlight the impact of research training on perceived competence, confidence, and capability to participate in research. 
Table 3 Theoretical Framework Summary of Study Outcomes

\begin{tabular}{|c|c|c|c|c|c|}
\hline $\begin{array}{l}\text { Author and } \\
\text { Yearl } \\
\text { Reference \# }\end{array}$ & $\begin{array}{l}\text { Type of } \\
\text { Participants }\end{array}$ & $\begin{array}{l}\text { Theoretical } \\
\text { Framework }\end{array}$ & Research Capacity & Attitude & Barriers \\
\hline $\begin{array}{l}\text { Akerjordet, } \\
\text { Lode, and } \\
\text { Severinsson } \\
2012^{83}\end{array}$ & Nurses & NIL & $\begin{array}{l}\text { Lacks confidence requires support } \\
>20 \% \text { wanted to improve research skills as did } \\
56 \% \text { of the } 8 \% \text { engaged in research }\end{array}$ & $\begin{array}{l}\text { Positive - utility value } \\
\text { Positive attitude to research by } 40 \% \text { all respondents }\end{array}$ & $\begin{array}{l}\text { Lack of designated time for research } \\
\text { Lack of organisational support } \\
\text { Lack of knowledge } \\
\text { Lack of support including acceptance by } \\
\text { colleagues, reward, and acknowledgement } \\
\text { Lack of interest in research }\end{array}$ \\
\hline $\begin{array}{l}\text { Albert et al } \\
2016^{67}\end{array}$ & Nurses & NIL & $\begin{array}{l}\text { Competent } \\
<42 \% \text { conducted research }\end{array}$ & $\begin{array}{l}\text { Positive - utility value } \\
\text { Mid-range scores for value and confidence in } \\
\text { conducting research }\end{array}$ & $\begin{array}{l}\text { Lack of knowledge } \\
\text { Lack of support including acceptance by } \\
\text { colleagues, reward, and acknowledgement } \\
\text { Access to literature }\end{array}$ \\
\hline $\begin{array}{l}\text { Alison, } \\
\text { Zafiropoulos, } \\
\text { and Heard } \\
2017^{64}\end{array}$ & Allied Health & NIL & $\begin{array}{l}\text { Lacks confidence requires support } \\
\text { Ten of the } 19 \text { items at the individual level had a } \\
\text { median score of } \leq 5\end{array}$ & $\begin{array}{l}\text { Positive - utility value } \\
\text { Main motivators to performing research reported } \\
\text { by participants included: to develop skills ( } 84 \% \text {, } \\
\mathrm{n}=2(0)\end{array}$ & $\begin{array}{l}\text { Lack of designated time for research } \\
\text { Lack of funding including incentives and failed } \\
\text { grants } \\
\text { Lack of training/resources/dedicated } \\
\text { research team } \\
\text { Lack of confidence, competence, skills, or } \\
\text { experience } \\
\text { Lack of organisational support } \\
\text { Lack of interest in research } \\
\text { Access to literature }\end{array}$ \\
\hline $\begin{array}{l}\text { Bench, Dowie- } \\
\text { Baker, and Fish } \\
2019^{74}\end{array}$ & Nurses & NIL & $\begin{array}{l}\text { Lacks confidence requires support } \\
27 \% \text { respondents had desire to be involved in } \\
\text { research. } 87 \% \text { reported never having published } \\
61 \% \text { never having presented at a conference }\end{array}$ & $\begin{array}{l}\text { Negative - no connection to researchers } \\
\text { Research not part of the role - Unpleasant and } \\
\text { scary }\end{array}$ & $\begin{array}{l}\text { Lack of designated time for research } \\
\text { Lack of confidence, competence, skills, or } \\
\text { experience } \\
\text { Lack of training/resources/dedicated } \\
\text { research team } \\
\text { Lack of knowledge }\end{array}$ \\
\hline
\end{tabular}

(Continued) 
Table 3 (Continued)

\begin{tabular}{|c|c|c|c|c|c|}
\hline $\begin{array}{l}\text { Author and } \\
\text { Yearl } \\
\text { Reference \# }\end{array}$ & $\begin{array}{l}\text { Type of } \\
\text { Participants }\end{array}$ & $\begin{array}{l}\text { Theoretical } \\
\text { Framework }\end{array}$ & Research Capacity & Attitude & Barriers \\
\hline $\begin{array}{l}\text { Berthelsen and } \\
\text { Holge-Hazelton } \\
2015^{84}\end{array}$ & Nurses & NIL & $\begin{array}{l}\text { Lacks confidence requires support } \\
\text { Interested in improving research skills }\end{array}$ & $\begin{array}{l}\text { Very positive - attainment, intrinsic and utility value. } \\
\text { Low theoretical knowledge and practical research } \\
\text { competencies }\end{array}$ & $\begin{array}{l}\text { Lack of designated time for research } \\
\text { Lack of confidence, competence, skills, or } \\
\text { experience } \\
\text { Lack of training/resources/dedicated } \\
\text { research team } \\
\text { Lack of support including acceptance by } \\
\text { colleagues, reward, and acknowledgement } \\
\text { Lack of interest in research }\end{array}$ \\
\hline $\begin{array}{l}\text { Borkowski, } \\
\text { McKinstry, and } \\
\text { Cotchett } 2017^{52}\end{array}$ & Allied Health & NIL & $\begin{array}{l}\text { Lacks confidence requires support } \\
\text { Low research capacity and culture with other } \\
\text { work roles taking priority and lack of time and } \\
\text { skills }\end{array}$ & $\begin{array}{l}\text { Positive - utility value } \\
\text { Focus on developing skills but unable to overcome } \\
\text { numerous barriers }\end{array}$ & $\begin{array}{l}\text { Lack of designated time for research } \\
\text { Lack of confidence, competence, skills, or } \\
\text { experience }\end{array}$ \\
\hline $\begin{array}{l}\text { Chan et al } \\
2011^{68}\end{array}$ & Nurses & NIL & $\begin{array}{l}\text { Lacks confidence requires support } \\
\text { Overwhelming lack of research experience but } \\
\text { highly interested }\end{array}$ & Very positive - attainment, intrinsic and utility value & $\begin{array}{l}\text { Lack of confidence, competence, skills, or } \\
\text { experience } \\
\text { Lack of knowledge } \\
\text { Lack of support including acceptance by } \\
\text { colleagues, reward, and acknowledgement }\end{array}$ \\
\hline $\begin{array}{l}\text { Choo, } \\
\text { Muninathan, } \\
\text { Pung, and } \\
\text { Ramanathan } \\
2017^{89}\end{array}$ & Physicians & NIL & $\begin{array}{l}\text { Competent } \\
34.8 \% \text { unlikely to participate in research under } \\
\text { present working conditions }\end{array}$ & $\begin{array}{l}\text { Negative - no connection to researchers } \\
\text { Identified research benefits for patients and society } \\
\text { (98.9\%) and professional development (93.3\%). } \\
\text { However, less than half perceive research to be one } \\
\text { of their job functions ( } 49.7 \%)\end{array}$ & $\begin{array}{l}\text { Lack of designated time for research } \\
\text { Lack of funding including incentives and failed } \\
\text { grants } \\
\text { Lack of training/resources/dedicated } \\
\text { research team } \\
\text { Lack of support including acceptance by } \\
\text { colleagues, reward, and acknowledgement }\end{array}$ \\
\hline $\begin{array}{l}\text { Cianciolo et al } \\
2020^{69}\end{array}$ & Physicians & $\begin{array}{l}\text { SCCT and } \\
\text { Professional } \\
\text { Identity } \\
\text { Formation }\end{array}$ & $\begin{array}{l}\text { Competent } \\
\text { Pakistan better alignment between clinicians' } \\
\text { research success and national priorities than U.S }\end{array}$ & $\begin{array}{l}\text { Very positive - attainment, intrinsic and utility value } \\
\text { Clinicians and scientists resilient in pursuing } \\
\text { research }\end{array}$ & $\begin{array}{l}\text { Lack of funding including incentives and failed } \\
\text { grants }\end{array}$ \\
\hline
\end{tabular}




\begin{tabular}{|c|c|c|c|c|c|}
\hline $\begin{array}{l}\text { Connolly, Allum, } \\
\text { Shaw, Pattison, } \\
\text { and Dark } 2018^{75}\end{array}$ & Physiotherapists & $\begin{array}{l}\text { COM-B } \\
\text { model. } \\
\text { capability, } \\
\text { opportunity, } \\
\text { motivation, } \\
\text { and behaviour }\end{array}$ & $\begin{array}{l}\text { Competent } \\
84.7 \% \text { indicated existing research experience. } \\
60.8 \% \text { had postgraduate qualifications at } \\
\text { master's level or above }\end{array}$ & $\begin{array}{l}\text { Very positive - attainment, intrinsic and utility value. } \\
24.2 \% \text { of respondents currently involved in } \\
\text { research. } 10.4 \% \text { not interested in any research } \\
\text { training. }\end{array}$ & $\begin{array}{l}\text { Lack of designated time for research } \\
\text { Lack of funding including incentives and failed } \\
\text { grants } \\
\text { Lack of confidence, competence, skills, or } \\
\text { experience }\end{array}$ \\
\hline $\begin{array}{l}\text { Conradie, Duys, } \\
\text { Forget, and } \\
\text { Biccard } 2018^{16}\end{array}$ & Physicians & NIL & $\begin{array}{l}\text { Lacks confidence requires support } \\
\text { Potential for research once barriers are } \\
\text { addressed. }\end{array}$ & Very positive - attainment, intrinsic and utility value & $\begin{array}{l}\text { Lack of training/resources/dedicated } \\
\text { research team } \\
\text { Lack of support including acceptance by } \\
\text { colleagues, reward, and acknowledgement. } \\
\text { Barriers to successful participation in ASOS } \\
\text { related to resource limitations and not } \\
\text { motivation of the clinician investigators. }\end{array}$ \\
\hline $\begin{array}{l}\text { Dannapfel, } \\
\text { Peolsson, and } \\
\text { Nilsen } 2013^{85}\end{array}$ & Physiotherapists & NIL & $\begin{array}{l}\text { Lacks confidence requires support } \\
\text { Research use } \\
\text { Changes in practice based on research findings, } \\
\text { which reflects changes in thinking rather than } \\
\text { actual behaviour }\end{array}$ & $\begin{array}{l}\text { Very positive - attainment, intrinsic and utility value } \\
\text { Positive attitudes to research and a strong } \\
\text { motivation to use research in clinical practice }\end{array}$ & $\begin{array}{l}\text { Lack of designated time for research } \\
\text { Lack of knowledge } \\
\text { Lack of confidence, competence, skills, or } \\
\text { experience } \\
\text { Lack of support including acceptance by } \\
\text { colleagues, reward, and acknowledgement } \\
\text { Access to literature }\end{array}$ \\
\hline $\begin{array}{l}\text { Dannapfel, } \\
\text { Peolsson, Stahl, } \\
\text { Oberg, and } \\
\text { Nilsen } 2014^{86}\end{array}$ & Physiotherapists & $\begin{array}{l}\text { Self- } \\
\text { determination } \\
\text { Theory SDT }\end{array}$ & $\begin{array}{l}\text { Lacks confidence requires support } \\
\text { Motivation measured along continuum of } \\
\text { autonomy from intrinsic - extrinsic-amotivated }\end{array}$ & $\begin{array}{l}\text { Very positive - attainment, intrinsic and utility value } \\
\text { Autonomous forms of motivation were most } \\
\text { common }\end{array}$ & Lack of interest in research \\
\hline $\begin{array}{l}\text { Elphinston and } \\
\text { Pager } 2015^{53}\end{array}$ & Psychologists & NIL & $\begin{array}{l}\text { Competent } \\
\text { Greater research } \\
\text { capacity of psychologists compared with other } \\
\text { allied health professions }\end{array}$ & $\begin{array}{l}\text { Negative - no connection to researchers } \\
\text { Majority of psychologists in } \\
\text { study perceived that research not part of their work } \\
\text { role }\end{array}$ & $\begin{array}{l}\text { Lack of designated time for research } \\
\text { Lack of funding including incentives and failed } \\
\text { grants } \\
\text { Lack of organisational support }\end{array}$ \\
\hline $\begin{array}{l}\text { Finch, Cornwell, } \\
\text { Nalder, and } \\
\text { Ward } 2015^{54}\end{array}$ & $\begin{array}{l}\text { Speech language } \\
\text { pathologists }\end{array}$ & NIL & $\begin{array}{l}\text { Lacks confidence requires support } \\
\text { Time constraints from their clinical caseload } \\
\text { greatly limited their research engagement }\end{array}$ & $\begin{array}{l}\text { Fear of research } \\
\text { Lack of research training was viewed as a key } \\
\text { obstacle preventing participants who were not } \\
\text { engaged in research from partaking in research } \\
\text { related activities }\end{array}$ & $\begin{array}{l}\text { Lack of designated time for research } \\
\text { Lack of organisational support } \\
\text { Lack of support including acceptance by } \\
\text { colleagues, reward, and acknowledgement } \\
\text { Lack of training/resources/dedicated } \\
\text { research team }\end{array}$ \\
\hline
\end{tabular}


Table 3 (Continued).

\begin{tabular}{|c|c|c|c|c|c|}
\hline $\begin{array}{l}\text { Author and } \\
\text { Yearl } \\
\text { Reference \# }\end{array}$ & $\begin{array}{l}\text { Type of } \\
\text { Participants }\end{array}$ & $\begin{array}{l}\text { Theoretical } \\
\text { Framework }\end{array}$ & Research Capacity & Attitude & Barriers \\
\hline $\begin{array}{l}\text { Harvey, } \\
\text { Plummer, } \\
\text { Nielsen, Adams, } \\
\text { and Pain } 2016^{55}\end{array}$ & Allied Health & NIL & $\begin{array}{l}\text { Lacks confidence requires support } \\
\text { Clinician researcher career trajectory }\end{array}$ & $\begin{array}{l}\text { Very positive - attainment, intrinsic and utility value } \\
\text { Predisposing personal qualities and exposure to } \\
\text { research facilitated a research debut by priming } \\
\text { participants to take advantage of workplace } \\
\text { opportunities for research. }\end{array}$ & $\begin{array}{l}\text { Lack of designated time for research } \\
\text { Lack of funding including incentives and failed } \\
\text { grants } \\
\text { Lack of organisational support } \\
\text { Lack of support including acceptance by } \\
\text { colleagues, reward, and acknowledgement }\end{array}$ \\
\hline $\begin{array}{l}\text { Hiscock et al } \\
2014^{56}\end{array}$ & $\begin{array}{l}\text { Allied Health, } \\
\text { Nurses, } \\
\text { Physicians }\end{array}$ & NIL & $\begin{array}{l}\text { Competent } \\
\text { Gender, age, occupation, and postgraduate } \\
\text { qualification - were significantly associated with } \\
\text { research activity }\end{array}$ & $\begin{array}{l}\text { Very positive - attainment, intrinsic and utility value } \\
\text { Research-inactive clinicians identified protected } \\
\text { research time as the key enabler of future research. }\end{array}$ & $\begin{array}{l}\text { Lack of designated time for research } \\
\text { Lack of organisational support } \\
\text { Lack of training/resources/dedicated } \\
\text { research team } \\
\text { Lack of support including acceptance by } \\
\text { colleagues, reward, and acknowledgement }\end{array}$ \\
\hline $\begin{array}{l}\text { Ito-lhara et al } \\
2013^{91}\end{array}$ & Physicians & NIL & $\begin{array}{l}\text { Competent } \\
\text { Physicians with experience in clinical trials }\end{array}$ & $\begin{array}{l}\text { Positive - utility value } \\
\text { Showed interest in conducting clinical trials }\end{array}$ & $\begin{array}{l}\text { Lack of designated time for research } \\
\text { Lack of funding including incentives and failed } \\
\text { grants } \\
\text { Lack of organisational support } \\
\text { Lack of training/resources/dedicated } \\
\text { research team } \\
\text { Lack of support including acceptance by } \\
\text { colleagues, reward, and acknowledgement } \\
\text { Unrealistic workload and tedious research } \\
\text { process }\end{array}$ \\
\hline $\begin{array}{l}\text { Janssen, Hale, } \\
\text { Mirfin-Veitch, } \\
\text { and Harland } \\
2016^{93}\end{array}$ & Physiotherapists & NIL & $\begin{array}{l}\text { Lacks confidence requires support } \\
56 \% \text { of subjects had not attended a research } \\
\text { course and } 60 \% \\
\text { Confidence in conducting research ranged from } \\
0 \text { to } 100 \text { [mean } 38 \text { (SD 27)] }\end{array}$ & $\begin{array}{l}\text { Positive - utility value } \\
\text { Physiotherapists were generally positive towards } \\
\text { research but struggled with the concept of research. } \\
\text { use of research vs participation in research. }\end{array}$ & $\begin{array}{l}\text { Lack of confidence, competence, skills, or } \\
\text { experience }\end{array}$ \\
\hline $\begin{array}{l}\text { Jones, Griffith, } \\
\text { Ubel, Stewart, } \\
\text { and Jagsi } 2016^{32}\end{array}$ & Physicians & NIL & $\begin{array}{l}\text { Competent } \\
\text { Attrition from academic medicine may be more } \\
\text { so due to a combination of conflicting values }\end{array}$ & $\begin{array}{l}\text { Very positive - attainment, intrinsic and utility value. } \\
\text { Elite sample of highly apt and research-motivated } \\
\text { clinician-investigators }\end{array}$ & $\begin{array}{l}\text { Lack of designated time for research } \\
\text { Lack of funding including incentives and failed } \\
\text { grants } \\
\text { Lack of support including acceptance by } \\
\text { colleagues, reward, and acknowledgement }\end{array}$ \\
\hline
\end{tabular}




\begin{tabular}{|c|c|c|c|c|c|}
\hline $\begin{array}{l}\text { Lowrie et al } \\
2015^{76}\end{array}$ & Pharmacists & NIL & $\begin{array}{l}\text { Lacks confidence requires support. Active } \\
\text { engagement in research is set out as a part of } \\
\text { the role however, saw research as an activity that } \\
\text { involved substantial personal cost for limited } \\
\text { personal gain. }\end{array}$ & $\begin{array}{l}\text { Negative - no connection to researchers } \\
\text { HSR for most pharmacists, for multiple reasons, } \\
\text { was viewed as an exceptional activity rather than a } \\
\text { core role. }\end{array}$ & $\begin{array}{l}\text { Lack of designated time for research } \\
\text { Lack of confidence, competence, skills, or } \\
\text { experience } \\
\text { Lack of organisational support } \\
\text { Lack of interest in research }\end{array}$ \\
\hline $\begin{array}{l}\text { Luckson, } \\
\text { Duncan, Rajai, } \\
\text { and Haigh } \\
2018^{79}\end{array}$ & $\begin{array}{l}\text { Allied Health, } \\
\text { Nurses }\end{array}$ & NIL & $\begin{array}{l}\text { Lacks confidence requires support } \\
\text { Individuals lacking adequate skills to undertake } \\
\text { most aspects of research. }\end{array}$ & $\begin{array}{l}\text { Positive - utility value } \\
\text { Partner with external links such as universities to do } \\
\text { research. }\end{array}$ & $\begin{array}{l}\text { Lack of confidence, competence, skills, or } \\
\text { experience } \\
\text { Lack of organisational support } \\
\text { Lack of knowledge } \\
\text { Lack of support including acceptance by } \\
\text { colleagues, reward, and acknowledgement }\end{array}$ \\
\hline $\begin{array}{l}\text { Mahmoud et al } \\
2011^{87}\end{array}$ & Physicians & NIL & $\begin{array}{l}\text { Lacks confidence requires support } \\
\text { Internet always source of literature search for } \\
96.1 \% \text { library } 28 \% \text {. }\end{array}$ & $\begin{array}{l}\text { Very positive - attainment, intrinsic and utility value. } \\
\text { Advancement of knowledge strongest motivator for } \\
\text { research } 78.4 \%\end{array}$ & $\begin{array}{l}\text { Lack of designated time for research } \\
\text { Lack of confidence, competence, skills, or } \\
\text { experience } \\
\text { Access to literature } \\
\text { Lack of research opportunities }\end{array}$ \\
\hline $\begin{array}{l}\text { Mansi, Karam, } \\
\text { and Chaaban } \\
2019^{70}\end{array}$ & Physicians & NIL & $\begin{array}{l}\text { Competent } \\
90 \% \text { of the residents reported previous research } \\
\text { experience during medical school, and } 71.6 \% \\
\text { reported research during their undergraduate } \\
\text { education }\end{array}$ & $\begin{array}{l}\text { Very positive - attainment, intrinsic and utility value. } \\
\text { More than half (56\%) of the residents surveyed } \\
\text { agreed that resident research is a positive } \\
\text { experience overall. }\end{array}$ & $\begin{array}{l}\text { Lack of designated time for research } \\
\text { Lack of knowledge } \\
\text { Lack of interest in research }\end{array}$ \\
\hline $\begin{array}{l}\text { Marshall et al } \\
2016^{65}\end{array}$ & $\begin{array}{l}\text { Allied Health, } \\
\text { Nurses, } \\
\text { Physicians }\end{array}$ & NIL & $\begin{array}{l}\text { Competent } \\
(\mathrm{n}=1 / 3 ; 75.3 \%) \text { reported they had actively } \\
\text { participated in ethics-approved research. }\end{array}$ & $\begin{array}{l}\text { Very positive - attainment, intrinsic and utility value. } \\
\text { Embedding research in clinical practice was critical } \\
\text { and should be seen as core business }\end{array}$ & $\begin{array}{l}\text { Lack of designated time for research } \\
\text { Lack of research opportunities }\end{array}$ \\
\hline $\begin{array}{l}\text { McDonald } \\
2020^{92}\end{array}$ & $\begin{array}{l}\text { Allied Health, } \\
\text { Nurses, } \\
\text { Physicians }\end{array}$ & NIL & $\begin{array}{l}\text { Lacks confidence requires support. Mainly } \\
\text { involved in applying for research ethics board } \\
\text { approvals, entering data, attending study start- } \\
\text { up and update meetings, and screening patients } \\
\text { for study eligibility. }\end{array}$ & $\begin{array}{l}\text { Positive - utility value } \\
\text { Overall, } 26 \% \text { were "very satisfied" and } 53 \% \text { were } \\
\text { "satisfied" with their jobs. }\end{array}$ & $\begin{array}{l}\text { Lack of designated time for research } \\
\text { Lack of support including acceptance by } \\
\text { colleagues, reward, and acknowledgement } \\
\text { Unrealistic workload and tedious research } \\
\text { process } \\
\text { Felt undervalued }\end{array}$ \\
\hline
\end{tabular}

(Continued) 
Table 3 (Continued).

\begin{tabular}{|c|c|c|c|c|c|}
\hline $\begin{array}{l}\text { Author and } \\
\text { Yearl } \\
\text { Reference \# }\end{array}$ & $\begin{array}{l}\text { Type of } \\
\text { Participants }\end{array}$ & $\begin{array}{l}\text { Theoretical } \\
\text { Framework }\end{array}$ & Research Capacity & Attitude & Barriers \\
\hline $\begin{array}{l}\text { McMaster, } \\
\text { Jammali-Blasi, } \\
\text { Andersson- } \\
\text { Noorgard, } \\
\text { Cooper, and } \\
\text { Mclnnes 201357 }\end{array}$ & Nurses & NIL & $\begin{array}{l}\text { Lacks confidence requires support } \\
\text { Majority of respondents reported no current } \\
\text { involvement in research }\end{array}$ & $\begin{array}{l}\text { Positive - utility value } \\
\text { Over half of participants in our study reported } \\
\text { having research goals for the following } 12 \text { months }\end{array}$ & $\begin{array}{l}\text { Lack of designated time for research } \\
\text { Lack of confidence, competence, skills, or } \\
\text { experience } \\
\text { Lack of organisational support } \\
\text { Lack of training/resources/dedicated } \\
\text { research team } \\
\text { Lack of interest in research }\end{array}$ \\
\hline $\begin{array}{l}\text { McNab, Berry, } \\
\text { and Skapetis } \\
2019^{58}\end{array}$ & $\begin{array}{l}\text { Allied Health, } \\
\text { Nurses }\end{array}$ & NIL & $\begin{array}{l}\text { Competent } \\
\text { Six one-hour face to face research lectures } \\
\text { improvement in self-reported levels of intention } \\
\text { to become involved in research as well as } \\
\text { research experience. }\end{array}$ & $\begin{array}{l}\text { Positive - utility value } \\
\text { Significant change in the self-assessed level of } \\
\text { experience was seen in a wide range of research } \\
\text { areas. }\end{array}$ & NIL \\
\hline Mills et al $2019^{3}$ & Physicians & NIL & $\begin{array}{l}\text { Competent } \\
49 \% \text { agreed that medical research is a lifestyle- } \\
\text { friendly career }\end{array}$ & $\begin{array}{l}\text { Positive - utility value } \\
\text { Improve human health, intellectual stimulation, and } \\
\text { career diversity }\end{array}$ & $\begin{array}{l}\text { Lack of designated time for research } \\
\text { Lack of funding including incentives and failed } \\
\text { grants } \\
\text { Lack of training/resources/dedicated } \\
\text { research team } \\
\text { Unrealistic workload and tedious research } \\
\text { process }\end{array}$ \\
\hline $\begin{array}{l}\text { Oliver-Baxter, } \\
\text { Brown, and } \\
\text { Mclntyre } 2017^{59}\end{array}$ & $\begin{array}{l}\text { Allied Health, } \\
\text { Nurses, } \\
\text { Physicians }\end{array}$ & NIL & $\begin{array}{l}\text { Competent } \\
\text { Higher research degree graduates completed } \\
\text { their RHD in the last } 5 \text { years }\end{array}$ & $\begin{array}{l}\text { Positive - utility value } \\
\text { Importance of connection/relatedness. Stayers are } \\
\text { more affiliated with professional organisation than } \\
\text { leavers. }\end{array}$ & $\begin{array}{l}\text { Lack of designated time for research } \\
\text { Lack of funding including incentives and failed } \\
\text { grants }\end{array}$ \\
\hline $\begin{array}{l}\text { Pager, Holden, } \\
\text { and Golenko } \\
2012^{60}\end{array}$ & Allied Health & NIL & $\begin{array}{l}\text { Competent } \\
43.9 \% \text { of all participants had postgraduate } \\
\text { qualifications. About half were required to do } \\
\text { research as part of their role description. }\end{array}$ & $\begin{array}{l}\text { Very positive - attainment, intrinsic and utility value } \\
\text { Desire to develop skills, increase job satisfaction, } \\
\text { and address identified problems }\end{array}$ & $\begin{array}{l}\text { Lack of designated time for research } \\
\text { Lack of funding including incentives and failed } \\
\text { grants } \\
\text { Lack of organisational support } \\
\text { Lack of training/resources/dedicated } \\
\text { research team } \\
\text { Lack of knowledge } \\
\text { Lack of support including acceptance by } \\
\text { colleagues, reward, and acknowledgement }\end{array}$ \\
\hline
\end{tabular}




\begin{tabular}{|c|c|c|c|c|c|}
\hline $\begin{array}{l}\text { Paget, Lilischkis, } \\
\text { Morrow, and } \\
\text { Caldwell 2014 }\end{array}$ & $\begin{array}{l}\text { Allied Health, } \\
\text { Nurses, } \\
\text { Physicians }\end{array}$ & NIL & $\begin{array}{l}\text { Competent } \\
\text { Most participants identified themselves as } \\
\text { having research skills or experience (63\%) or } \\
\text { formal research training }(66 \%)\end{array}$ & $\begin{array}{l}\text { Very positive - attainment, intrinsic and utility value. } \\
\text { Enjoy participating in research }(68 \%) \text { and the } \\
\text { departments value research }(66 \%)\end{array}$ & $\begin{array}{l}\text { Lack of designated time for research } \\
\text { Lack of funding including incentives and failed } \\
\text { grants } \\
\text { Lack of organisational support } \\
\text { Lack of training/resources/dedicated } \\
\text { research team } \\
\text { Lack of support including acceptance by } \\
\text { colleagues, reward, and acknowledgement }\end{array}$ \\
\hline $\begin{array}{l}\text { Pain, Petersen, } \\
\text { and Fernando } \\
2018^{61}\end{array}$ & Allied Health & NIL & $\begin{array}{l}\text { Lacks confidence requires support. Research } \\
\text { experience increased from } 2011 \text { to } 2015 \text { as did } \\
\text { the need for support. Conducting research was } \\
\text { part of role description. }\end{array}$ & $\begin{array}{l}\text { Positive - utility value } \\
\text { Make a difference in clinical care (56.8\%) and } \\
\text { evaluate their service (52.6\%). }\end{array}$ & Lack of designated time for research \\
\hline $\begin{array}{l}\text { Sarwar et al } \\
2018^{80}\end{array}$ & Pharmacists & NIL & $\begin{array}{l}\text { Competent } \\
\text { Majority of the respondents }(\mathrm{n}=|| 2,86.2 \%) \\
\text { agreed } \\
\text { with the statement "I have the required } \\
\text { abilities to participate in research". }\end{array}$ & $\begin{array}{l}\text { Positive - utility value } \\
\text { Uplifting of the profession, } \\
\text { opportunity to gain knowledge, provide better } \\
\text { services and increased patient care. }\end{array}$ & $\begin{array}{l}\text { Lack of designated time for research } \\
\text { Lack of funding including incentives and failed } \\
\text { grants } \\
\text { Lack of knowledge } \\
\text { Lack of research opportunities }\end{array}$ \\
\hline $\begin{array}{l}\text { Scala, Patterson, } \\
\text { Stavarski, and } \\
\text { Mackay } 2019^{71}\end{array}$ & Nurses & $\begin{array}{l}\text { Vroom's } \\
\text { expectancy } \\
\text { theory } \\
\text { framework: }\end{array}$ & $\begin{array}{l}\text { Competent } \\
7 \text { (20.6\%) Master's degree }\end{array}$ & $\begin{array}{l}\text { Positive - utility value } \\
\text { Feeling empowered to make a difference and } \\
\text { legitimize the profession }\end{array}$ & Lack of organisational support \\
\hline $\begin{array}{l}\text { Siedlecki and } \\
\text { Albert } 2016^{72}\end{array}$ & Nurses & $\begin{array}{l}\text { Research- } \\
\text { Active Nurse } \\
\text { Model }\end{array}$ & $\begin{array}{l}\text { Competent } \\
65 \% \text { Master's Degree }\end{array}$ & $\begin{array}{l}\text { Very positive - attainment, intrinsic and utility value. } \\
\text { Passion for enquiry; they enjoyed the process, } \\
\text { despite the work and personal time involved. }\end{array}$ & $\begin{array}{l}\text { Lack of designated time for research } \\
\text { Lack of funding including incentives and failed } \\
\text { grants } \\
\text { Lack of knowledge }\end{array}$ \\
\hline $\begin{array}{l}\text { Silberman et al } \\
2012^{73}\end{array}$ & Physicians & NIL & $\begin{array}{l}\text { Competent } \\
30.7 \% \text { had master's or doctoral degrees in } \\
\text { addition to medical degrees. }\end{array}$ & $\begin{array}{l}\text { Very positive - attainment, intrinsic and utility value. } \\
\text { Had a consistent pattern of interest and } \\
\text { involvement in research, starting well before } \\
\text { residency. }\end{array}$ & $\begin{array}{l}\text { Lack of funding including incentives and failed } \\
\text { grants } \\
\text { Barriers specific to women }\end{array}$ \\
\hline $\begin{array}{l}\text { Snelgrove and } \\
\text { James } 2011^{77}\end{array}$ & Nurses & NIL & $\begin{array}{l}\text { Competent } \\
\text { Most participants had completed or were } \\
\text { completing a master's level degree }\end{array}$ & $\begin{array}{l}\text { Research frightening/Lack of connection and } \\
\text { institutional support. Despite positive attitudes and } \\
\text { some research education, many of the participants } \\
\text { described research as 'frightening', with a lack of } \\
\text { skills cited as a determinant of this fear }\end{array}$ & $\begin{array}{l}\text { Lack of organisational support } \\
\text { Lack of training/resources/dedicated } \\
\text { research team }\end{array}$ \\
\hline
\end{tabular}


Table 3 (Continued).

\begin{tabular}{|c|c|c|c|c|c|}
\hline $\begin{array}{l}\text { Author and } \\
\text { Yearl } \\
\text { Reference \# }\end{array}$ & $\begin{array}{l}\text { Type of } \\
\text { Participants }\end{array}$ & $\begin{array}{l}\text { Theoretical } \\
\text { Framework }\end{array}$ & Research Capacity & Attitude & Barriers \\
\hline $\begin{array}{l}\text { Stewart et al } \\
2015^{81}\end{array}$ & Pharmacists & NIL & $\begin{array}{l}\text { Competent } \\
\text { One third }(32.9 \%, \mathrm{n}=70) \text { had completed a } \\
\text { postgraduate course, one third }(30.0 \%, \mathrm{n}=64) \\
\text { were currently studying for a postgraduate } \\
\text { qualification. }\end{array}$ & $\begin{array}{l}\text { Positive - utility value } \\
\text { Generally held positive attitudes, with a median } \\
\text { overall score of I } 3 \text { (IQR 8-18), range possible } \\
8-40 \text {, with } 8 \text { representing best positive attitudinal } \\
\text { score }\end{array}$ & $\begin{array}{l}\text { Lack of organisational support } \\
\text { Lack of training/resources/dedicated } \\
\text { research team }\end{array}$ \\
\hline $\begin{array}{l}\text { Stewart et al } \\
2019^{78}\end{array}$ & Pharmacists & $\begin{array}{l}\text { Theoretical } \\
\text { Domains } \\
\text { Framework } \\
\text { TDF }\end{array}$ & $\begin{array}{l}\text { Competent } \\
\text { Postgraduate qualifications } 58.1 \%(79) 14.7 \% \\
(n=20) \text { had been involved in research in the past } \\
\text { and had plans to be involved in the future, and } \\
12.5 \%(n=17) \text { were currently involved in } \\
\text { research. }\end{array}$ & $\begin{array}{l}\text { Positive - utility value } \\
\text { Attainment value - } 94 \% \text { benefit to profession. } \\
\text { Utility value - benefit to patients } 90.45 \text { benefit to } \\
\text { self- } 72.6 \% \text {. }\end{array}$ & $\begin{array}{l}\text { Lack of designated time for research } \\
\text { Lack of organisational support } \\
\text { Lack of support including acceptance by } \\
\text { colleagues, reward, and acknowledgement }\end{array}$ \\
\hline $\begin{array}{l}\text { Sultana, Al } \\
\text { Jeraisy, Al } \\
\text { Ammari, Patel, } \\
\text { and Zaidi } 2016^{82}\end{array}$ & Pharmacists & $\begin{array}{l}\text { Social } \\
\text { cognitive } \\
\text { theory }\end{array}$ & $\begin{array}{l}\text { Competent } \\
\text { Prior research experience was reported by } 59 \% \\
\text { of participants. } \\
\text { More than } 40 \% \text { of participants hold Masters } \\
\text { degree in pharmacy. }\end{array}$ & $\begin{array}{l}\text { Positive - utility value } \\
70 \% \text { of the participants were interested in doing } \\
\text { practice-based research with nearly half willing to } \\
\text { make time for it. }\end{array}$ & $\begin{array}{l}\text { Lack of designated time for research } \\
\text { Lack of organisational support } \\
\text { Lack of research opportunities }\end{array}$ \\
\hline $\begin{array}{l}\text { Torres et al } \\
2017^{90}\end{array}$ & Nurses & NIL & $\begin{array}{l}\text { Competent } \\
\text { Perceived knowledge and skills of the research } \\
\text { process were above } 3 \text { on a 5-point scale (means } \\
\text { ranged between } 3.14 \text { and 4.06). }\end{array}$ & $\begin{array}{l}\text { Positive - utility value } \\
\text { Professional advancement, tenure and promotion, } \\
\text { research record }\end{array}$ & $\begin{array}{l}\text { Lack of confidence, competence, skills, or } \\
\text { experience } \\
\text { Lack of knowledge } \\
\text { Unrealistic workload and tedious research } \\
\text { process }\end{array}$ \\
\hline $\begin{array}{l}\text { van Hoving and } \\
\text { Brysiewicz } \\
2017^{88}\end{array}$ & $\begin{array}{l}\text { Physicians, } \\
\text { Nurses }\end{array}$ & NIL & $\begin{array}{l}\text { Competent } \\
\text { Honours or Masters degree - } 44 \text { (26.2\%). } \\
\text { Doctoral degree - } 35 \text { (20.8\%) }\end{array}$ & $\begin{array}{l}\text { Positive - utility value } \\
\text { Improvement of research skills (70.2\%) and having } \\
\text { research published }(69.6 \%)\end{array}$ & $\begin{array}{l}\text { Lack of designated time for research } \\
\text { Lack of funding including incentives and failed } \\
\text { grants } \\
\text { Lack of training/resources/dedicated } \\
\text { research team } \\
\text { Access to literature }\end{array}$ \\
\hline
\end{tabular}




\begin{tabular}{|c|c|}
\hline 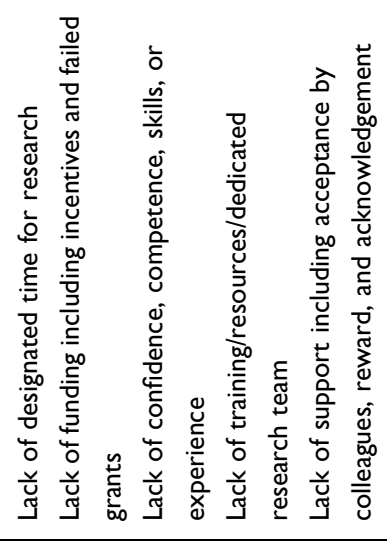 & 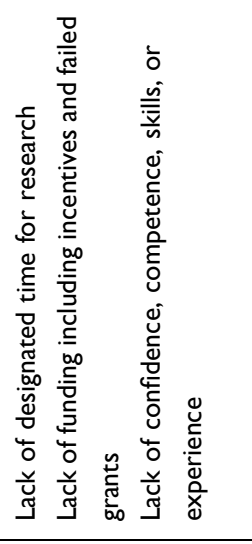 \\
\hline 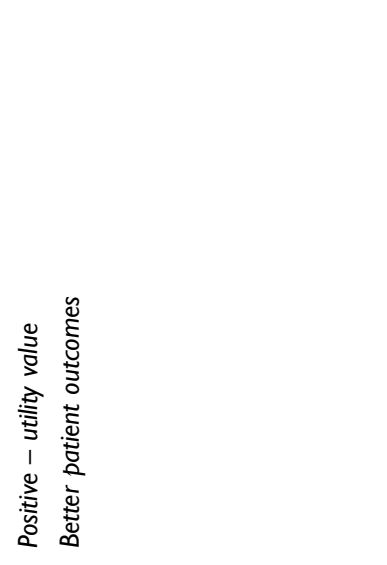 & 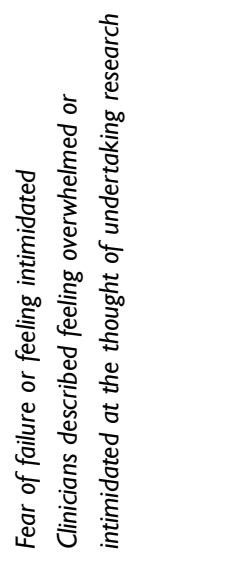 \\
\hline 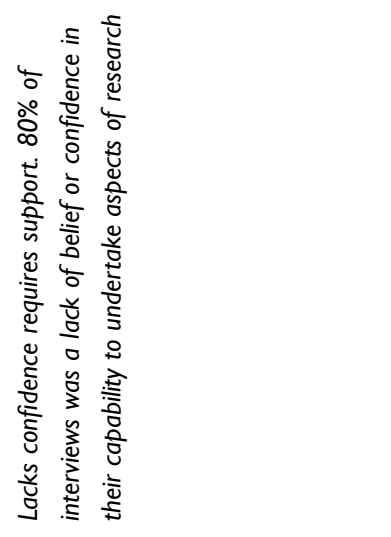 & 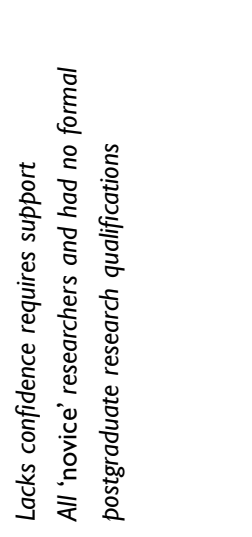 \\
\hline$\vec{z}$ & 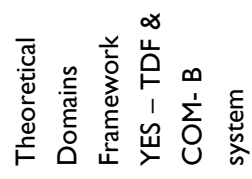 \\
\hline 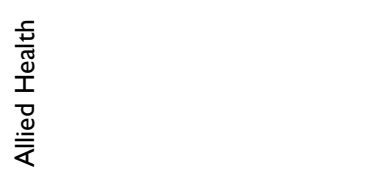 & 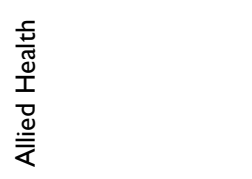 \\
\hline 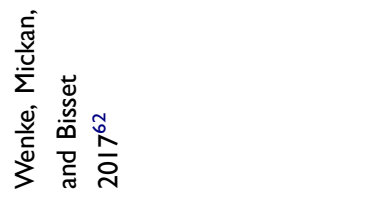 & 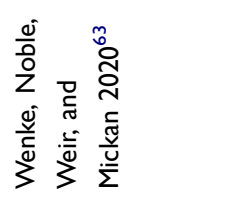 \\
\hline
\end{tabular}

HPs Attitude - This Relates to Value and Connection As depicted in Table 3, participants' attitude to research was assessed as very positive in 17 (38\%) studies,$16,32,55,56,60,65,66,68-70,72,73,75,84-87$ positive in 21 (47\%) studies $^{3,52,57-59,61,62,64,67,71,78-83,88,90-93}$ and negative in four $(9 \%)^{53,74,76,89}$ studies.

The 17 studies in which HPs were deemed very positive included six on medical doctors, ${ }^{16,32,69,70,73,87}$ five on AHPs, ${ }^{55,60,75,85,86}$ three on nurses ${ }^{55,60,75,85,86}$ and three on a combination of the three groups. ${ }^{56,65,66}$ The 21 studies that identified respondents as positive comprised nine on AHPs, ${ }^{52,61,62,64,78,80-82,93}$ (including four on pharmacists${ }^{78,80-82}$ and one on physiotherapists), ${ }^{93}$ five on nurses,$57,67,71,83,90$ two on medical doctors ${ }^{3,91}$ and five on a combination of the HP groups - two focused on all three HP groups, ${ }^{59,92}$ two on AHPs and nurses ${ }^{58,79}$ and one on medical doctors and nurses ${ }^{88}$ The four studies in which HPs were identified as negative included two on AHPs pharmacists $^{76}$ and psychologists, ${ }^{53}$ one each on nurses ${ }^{74}$ and medical doctors. ${ }^{89}$ Another three studies reported their respondents as being afraid of research - two on $\mathrm{AHPs}^{54,63}$ and one on nurses. ${ }^{77}$

Generally, participants who demonstrated very positive attitude towards research were keen to contribute to clinical practice by engaging in collaborative research to advance clinical knowledge and improve patient health outcomes (utility value). Additionally, they were avidly interested in publishing, producing new knowledge, gaining grants and getting respect of colleagues (attainment value) as well as broadening personal scope of professional career and becoming knowledgeable researchers with genuine interest in research as a problem-solving tool $^{32,55,69,87}$ (intrinsic value). This group of participants had genuine curiosity and willingness to learn, were mostly satisfied with their jobs, wanted to develop research skills so they could increase knowledge and develop cutting edge research that proffer solutions to clinical problems. ${ }^{55,60,75,85,86}$ They also felt a strong connection to research and their profession bodies. For example, research active pharmacists reported the importance of research in uplifting the pharmacy profession and enjoyed reading articles. ${ }^{80,82}$

Participants who demonstrated positive attitude mainly viewed research as beneficial for making a difference in clinical care with improved patient health outcomes and service delivery. ${ }^{16,70,73,91}$ This group focused on the utility of research and mainly focused on its benefits in improving clinical care and practice. For participants who were 
negative, the common attitude reported included perceived benefit only for the institution in which they worked. ${ }^{89}$ They also did not feel supported by their organisation and therefore did not consider research as part of their role. Interestingly, one study on the medical group identified its participants as negative/not involved in research and perceived the value of research as solely for the benefit of patients and the institution in which they worked. ${ }^{89}$ Nurses were negative in one study ${ }^{74}$ and found research frightening in another. ${ }^{77}$ Two studies on AHPs fell under the fear of research category. ${ }^{54,63}$ This group of participants reported minuscule ${ }^{63}$ or no value ${ }^{54}$ for research and emphasised the need for connection and relatedness. Participants in the negative/fear of research groups were of the opinion that research was a "huge undertaking" and "daunting task". 57

Overall, most of the participants in the medical group were very positive while the AHP and nursing groups were mostly in the positive category. Intrinsic value was seen as a pre-requisite for motivation, while utility value is the trigger for research to satisfy the need in clinical practice. ${ }^{72}$ The results suggest that very positive attitude towards research is based on intrinsic and attainment values and these help the HPs develop strong long-term connection with research. On the other hand, negative attitude seemed to be linked to perceived low organisational support for research. Although participants with negative attitude acknowledged that research could improve clinical practice and boost professional reputation, but feelings of poor connection to research team created disillusion or fear. These findings indicate that sense of value and connection could be paramount in determining HPs' level of motivation to engage with research.

\section{HPs Barriers to Undertaking Research Relates to Cost and Autonomy}

Table 4 depicts the barriers identified by the participant groups. The most frequently reported barriers to undertaking research were lack of time and funding. Lack of designated time for research was reported in 32 (71\%) studies $3,32,52-57,59-66,70,72,74-76,78,80,82-85,87-89,91,92 \quad$ while lack of funding (including incentives and failed grants) was identified as a significant barrier to conducting research in $18(40 \%)$ studies, mostly by the medical
Table 4 Major Types of Barriers by Participant Groups

\begin{tabular}{|c|c|c|}
\hline Participants & $\begin{array}{l}\text { Number of studies } \\
\text { and \# }\end{array}$ & Major Barriers \\
\hline $\begin{array}{l}\text { Physicians } \\
\text { AH, Nurses, } \\
\text { Physicians } \\
\text { Physicians, Nurses } \\
\text { AH } \\
\text { Nurses }\end{array}$ & $\begin{array}{l}6^{3,32,69,73,89,91} \\
2^{59,66} \\
1^{88} \\
8^{53,55,60,62-64,75,80} \\
1^{72}\end{array}$ & $\begin{array}{l}\text { Lack of funding including } \\
\text { incentives and failed } \\
\text { grants }\end{array}$ \\
\hline Total & 18 & \\
\hline $\begin{array}{l}\text { AH } \\
\text { Nurses } \\
\text { AH, Nurses } \\
\text { Physicians }\end{array}$ & $\begin{array}{l}8^{62-64,75,76,85,93,94} \\
5^{57,68,74,84,90} \\
1^{79} \\
1^{87}\end{array}$ & $\begin{array}{l}\text { Lack of confidence, } \\
\text { competence, skills, or } \\
\text { experience }\end{array}$ \\
\hline Total & 15 & \\
\hline $\begin{array}{l}\text { AH } \\
\text { Nurses } \\
\text { AH, Nurses, } \\
\text { Physicians } \\
\text { AH, Nurses } \\
\text { Physicians }\end{array}$ & $\begin{array}{l}9^{53-55,60,64,76,78,81,82} \\
4^{57,71,77,83} \\
2^{56,66} \\
1^{79} \\
1^{91}\end{array}$ & $\begin{array}{l}\text { Lack of organisational } \\
\text { support }\end{array}$ \\
\hline Total & 17 & \\
\hline $\begin{array}{l}\text { AH } \\
\text { Nurses } \\
\text { Physicians } \\
\text { AH, Nurses, } \\
\text { Physicians } \\
\text { Physicians, Nurses }\end{array}$ & $\begin{array}{l}4^{60,62,64,81} \\
4^{57,74,77,84} \\
4^{3,16,89,91} \\
2^{56,66} \\
1^{88}\end{array}$ & $\begin{array}{l}\text { Lack of training/ } \\
\text { resources/dedicated } \\
\text { research team }\end{array}$ \\
\hline Total & 15 & \\
\hline $\begin{array}{l}\text { Nurses } \\
\text { AH } \\
\text { AH, Nurses } \\
\text { Physician }\end{array}$ & $\begin{array}{l}6^{67,68,72,74,83,90} \\
3^{80,85,95} \\
1^{79} \\
1^{70}\end{array}$ & Lack of knowledge \\
\hline Total & 11 & \\
\hline $\begin{array}{l}\text { AH } \\
\text { Physicians } \\
\text { Nurses } \\
\text { AH, Nurses, } \\
\text { Physicians } \\
\text { AH, Nurses }\end{array}$ & $\begin{array}{l}5^{55,60,62,78,85} \\
3^{16,32,91} \\
2^{68,84} \\
2^{66,92} \\
1^{79}\end{array}$ & $\begin{array}{l}\text { Lack of support } \\
\text { (including acceptance by } \\
\text { colleagues, reward, and } \\
\text { acknowledgement) }\end{array}$ \\
\hline Total & 13 & \\
\hline $\begin{array}{l}\text { AH } \\
\text { Nurses } \\
\text { AH, Nurses, } \\
\text { Physicians } \\
\text { Physicians }\end{array}$ & $\begin{array}{l}2^{54,60} \\
2^{67,83} \\
2^{56,66} \\
2^{89,91}\end{array}$ & $\begin{array}{l}\text { Lack of supervisors/ } \\
\text { mentors }\end{array}$ \\
\hline Total & 8 & \\
\hline
\end{tabular}

(Continued) 
Table 4 (Continued).

\begin{tabular}{|c|c|c|}
\hline Participants & $\begin{array}{l}\text { Number of studies } \\
\text { and \# }\end{array}$ & Major Barriers \\
\hline $\begin{array}{l}\mathrm{AH} \\
\text { Nurses } \\
\text { Physicians }\end{array}$ & $\begin{array}{l}3^{64,76,86} \\
3^{57,83,84} \\
1^{70}\end{array}$ & $\begin{array}{l}\text { Lack of interest in } \\
\text { research }\end{array}$ \\
\hline Total & 7 & \\
\hline $\begin{array}{l}\text { AH } \\
\text { Nurses } \\
\text { AH, Nurses, } \\
\text { Physicians } \\
\text { Physicians }\end{array}$ & $\begin{array}{l}1^{64} \\
1^{90} 1^{88} \\
2^{3,91}\end{array}$ & $\begin{array}{l}\text { Unrealistic workload } \\
\text { and tedious research } \\
\text { process }\end{array}$ \\
\hline Total & 5 & \\
\hline $\begin{array}{l}\text { AH } \\
\text { Nurses } \\
\text { Physicians, Nurses } \\
\text { Physicians }\end{array}$ & $\begin{array}{l}2^{64,85} \\
1^{67} \\
1^{88} \\
1^{87}\end{array}$ & Access to literature \\
\hline Total & 5 & \\
\hline $\begin{array}{l}\text { AH } \\
\text { AH, Nurses, } \\
\text { Physicians } \\
\text { Physicians }\end{array}$ & $\begin{array}{l}2^{80,82} \\
1^{65} \\
1^{87}\end{array}$ & $\begin{array}{l}\text { Lack of research } \\
\text { opportunities }\end{array}$ \\
\hline Total & 4 & \\
\hline $\begin{array}{l}\text { AH, Nurses, } \\
\text { Physicians }\end{array}$ & $1^{92}$ & Felt undervalued \\
\hline Total & 1 & \\
\hline Physicians & $1^{73}$ & $\begin{array}{l}\text { Barriers specific to } \\
\text { women }\end{array}$ \\
\hline Total & 1 & \\
\hline
\end{tabular}

doctors, $3,32,59,66,69,73,88,89,91$ followed by the AHPs $^{53,55,60,62-64,75,80}$ and nurses. ${ }^{72,88}$

Respondents in 15 (33\%) studies reported lack of confidence, competence, skills and/or research experience,$57,62-64,68,74-76,79,84,85,87,90,93,94$ while 17 (38\%) studies reported lack of organisational support as a significant barrier to research involvement ${ }^{53-57,60,64,66,71,76-79,81-83,91}$ Lack of research competence and organisational support were mostly flagged by the AHPs, ${ }^{52-55,60,62-}$ $64,75,76,78,79,81,82,85,93$ followed by the nurses$57,68,71,74,77,83,84,90$ and only few medical doctors. ${ }^{87,91}$

Lack of training/resources/dedicated research team was mentioned by participant groups in 15 studies (33\%)$3,16,56,57,60,62,64,66,74,77,81,84,88,89,91$ Lack of knowledge was of concern in 11 studies (24\%) and mostly acknowledged by the nursing group, ${ }^{67,68,72,74,83,90}$ followed by the AHPs $^{79,80,85,95}$ and the medical group. ${ }^{70}$ Lack of support (including acceptance by colleagues, reward and acknowledgement) was mentioned in 13 studies (29\%) and mostly indicated by AHPs, ${ }^{55,60,62,78,85}$ and the medical group. ${ }^{16,32,91}$ Eight studies (18\%) reported lack of supervision/mentors, ${ }^{54,56,60,66,67,83,89,91}$ seven studies $(16 \%)$ reported lack of interest in research.57,64,70,76,83,84,86 Five studies each (11\%) identified unrealistic workload/tedious research process ${ }^{3,64,90-92}$ and access to literature as barriers to research, while lack of research opportunities was reported in 4 studies (9\%).$65,80,82,87$ Participants felt undervalued in one study ${ }^{92}$ while another study found barriers specific to women ${ }^{73}$ as a deterrent to their participation in research.

Overall, AHPs reported more barriers than nurses and medical doctors, particularly in relation to lack of organisational support, confidence, training, and acceptance by colleagues. Major barriers for nurses were lack of knowledge, training, and confidence; while for medical doctors, it was lack of funding. The results show that the AHPs and nurses were less able to demonstrate autonomy to engage with research in comparison to the medical doctors and they were mostly limited by lack of knowledge, training, and confidence which are important pre-requisites of research capability. This finding indicates that just as research knowledge and training can foster confidence and competence, lack of them can also serve as major and costly barriers that limit HPs' capacity to participate in research.

\section{Integration of the Elements of the Conceptual Frameworks}

Integration of the findings based on the $\mathrm{EVC}^{33,34}$ and $\mathrm{SDT}^{40,41}$ theories indicate strong interactions between the three components - research capacity (expectancy and competence), attitude (value and connection), and barriers (cost and autonomy). Table 5 presents the relationship between the components that influence motivation to engage in research. Generally, HPs who were reported as competent (mostly studies on medical doctors or combination of all three groups ${ }^{32,56,60,65,66,69,70,72,73,75}$ ) had prior exposure to research training either in their undergraduate or postgraduate education. This boosted their confidence and facilitated interest and connection with research in their career paths. In addition, engagement with research was based on the type of value (utility, intrinsic and attainment) HPs attached to research. Those who were 
Table 5 Integration of Theoretical Framework Elements by Participant Groups

\begin{tabular}{|c|c|c|c|c|c|}
\hline $\begin{array}{l}\text { Research } \\
\text { Capacity }\end{array}$ & Attitude & Participants & Numbers & Major Barriers & Summary \\
\hline \multirow[t]{2}{*}{ Competent } & $\begin{array}{l}\text { Very positive - } \\
\text { attainment, intrinsic } \\
\text { and utility value }\end{array}$ & $\begin{array}{l}\mathrm{AH} \\
\mathrm{AH} \\
\text { Physiotherapists } \\
\text { AH, Nurses, } \\
\text { Physicians } \\
\text { Physicians } \\
\text { Nurses }\end{array}$ & $\begin{array}{l}1^{60} \\
1^{75} \\
3^{56,65,66} \\
4^{32,69,70,73} \\
1^{72}\end{array}$ & Multiple barriers & $\begin{array}{l}\text { Demonstrated all three types of value, felt connected to other research colleagues and } \\
\text { despite multiple barriers, they had genuine interest which fostered their capacity for on- } \\
\text { going, long-term research. } \\
\text { Viewed research as highly beneficial in advancing clinical knowledge, improving patient } \\
\text { health outcome (utility value), producing new knowledge, gaining recognition (attainment } \\
\text { value) as well as broadening personal scope of professional career and building sustainable } \\
\text { problem-solving systems to identify solutions to key clinical problems (intrinsic value). }\end{array}$ \\
\hline & & Total & 10 & & \\
\hline \multirow[t]{2}{*}{ Competent } & Positive - utility value & $\begin{array}{l}\text { AH Pharmacists } \\
\text { AH, Nurses } \\
\text { AH, Nurses, } \\
\text { Physicians } \\
\text { Physicians } \\
\text { Physicians, } \\
\text { Nurses } \\
\text { Nurses }\end{array}$ & $\begin{array}{l}4^{78,80-82} \\
1^{58} \\
1^{59} \\
2^{3,91} \\
1^{88} \\
3^{67,71,90}\end{array}$ & Multiple barriers & $\begin{array}{l}\text { Competent and positive in their attitude, but they exhibited only utility value because } \\
\text { connection with professional organisation was lacking }\end{array}$ \\
\hline & & Total & 12 & & \\
\hline \multirow[t]{2}{*}{ Competent } & $\begin{array}{l}\text { Negative - no } \\
\text { connection to } \\
\text { researchers }\end{array}$ & $\begin{array}{l}\text { AH } \\
\text { Psychologists } \\
\text { Physicians }\end{array}$ & $1^{53}$ & Lack of organisational support & $\begin{array}{l}\text { High confidence/competence levels, but they were negative and feared research } \\
\text { Perception that research was not part of their job roles and there was no organisational } \\
\text { support, so they did not see the connection with the research community }\end{array}$ \\
\hline & & Total & 2 & & \\
\hline \multirow[t]{3}{*}{ Competent } & Fear of Research & Nurses & $\mathrm{I}^{77}$ & $\begin{array}{l}\text { Lack of organisational support } \\
\text { Lack of training/resources/dedicated } \\
\text { research team }\end{array}$ & As above \\
\hline & & Total & 1 & & \\
\hline & & $\begin{array}{l}\text { Total } \\
\text { Competent }\end{array}$ & 25 & & \\
\hline
\end{tabular}




\begin{tabular}{|c|c|c|c|c|c|}
\hline $\begin{array}{l}\text { Lacks } \\
\text { confidence } \\
\text { requires } \\
\text { support }\end{array}$ & $\begin{array}{l}\text { Very positive - } \\
\text { attainment, intrinsic } \\
\text { and utility value }\end{array}$ & $\begin{array}{l}\text { AH } \\
\text { AH } \\
\text { Physiotherapists } \\
\text { Physicians } \\
\text { Nurses }\end{array}$ & $\begin{array}{l}1^{55} \\
2^{85,86} \\
2^{16,87} \\
2^{68,84}\end{array}$ & $\begin{array}{l}\text { Lack of organisational support } \\
\text { Lack of training/resources/dedicated } \\
\text { research team }\end{array}$ & $\begin{array}{l}\text { Lacked confidence but because of their predisposing personal qualities and exposure to } \\
\text { research, which was facilitated by workplace research opportunities, they had very } \\
\text { positive attitude towards research }\end{array}$ \\
\hline & & Total & 7 & & \\
\hline \multirow[t]{2}{*}{$\begin{array}{l}\text { Lacks } \\
\text { confidence } \\
\text { requires } \\
\text { support }\end{array}$} & Positive - utility value & $\begin{array}{l}\text { AH } \\
\text { AH } \\
\text { Physiotherapists } \\
\text { AH, Nurses } \\
\text { AH, Nurses, } \\
\text { Physicians } \\
\text { Nurses }\end{array}$ & $\begin{array}{l}4^{52,61,62,64} \\
1^{93} \\
1^{79} \\
1^{92} \\
2^{57,83}\end{array}$ & $\begin{array}{l}\text { Lack of organisational support } \\
\text { Lack of training/resources/dedicated } \\
\text { research team } \\
\text { Lack of support including } \\
\text { acceptance by colleagues, reward, } \\
\text { and acknowledgement }\end{array}$ & Perceived only the utility value \\
\hline & & Total & 9 & & \\
\hline \multirow[t]{2}{*}{$\begin{array}{l}\text { Lacks } \\
\text { confidence } \\
\text { requires } \\
\text { support }\end{array}$} & $\begin{array}{l}\text { Negative - no } \\
\text { connection to } \\
\text { researchers }\end{array}$ & $\begin{array}{l}\text { AH Pharmacists } \\
\text { Nurses }\end{array}$ & $\begin{array}{l}1^{76} \\
1^{74}\end{array}$ & $\begin{array}{l}\text { Lack of organisational support } \\
\text { Lack of training/resources/dedicated } \\
\text { research team } \\
\text { Lack of knowledge }\end{array}$ & Perceived that it had no value and involved a lot of personal cost for limited personal gain \\
\hline & & Total & 2 & & \\
\hline \multirow[t]{3}{*}{$\begin{array}{l}\text { Lacks } \\
\text { confidence } \\
\text { requires } \\
\text { support }\end{array}$} & Fear of Research & $\begin{array}{l}\text { AH } \\
\text { AH Speech } \\
\text { language } \\
\text { pathologists }\end{array}$ & $\begin{array}{l}1^{63} \\
1^{54}\end{array}$ & $\begin{array}{l}\text { Lack of organisational support } \\
\text { Lack of training/resources/dedicated } \\
\text { research team }\end{array}$ & Perceived that it had no value and involved a lot of personal cost for limited personal gain \\
\hline & & Total & 2 & & \\
\hline & & $\begin{array}{l}\text { Total Lacks } \\
\text { confidence } \\
\text { requires } \\
\text { support }\end{array}$ & 20 & & \\
\hline
\end{tabular}

Abbreviations: EVC, expectancy-value theory; SDT, self-determination theory; HMR, translational health and medical research; HPs, health professionals; PRISMA, Preferred Reporting Items for Systematic Reviews and Meta-Analyses; EVC, expectancy-value-cost model of motivation; QATSDD, Quality Assessment Tool for Studies with Diverse Designs. 
very positive demonstrated all three types of value, felt connected to other research colleagues and despite multiple barriers, they had genuine interest which fostered their capacity for on-going, long-term research. They viewed research as highly beneficial in advancing clinical knowledge, improving patient health outcomes (utility value), producing new knowledge, gaining recognition (attainment value) as well as broadening personal scope of professional career and building sustainable problem-solving systems to identify solutions to key clinical problems (intrinsic value). Some HPs (mostly AHPs and nurses) were competent and positive in their attitude, but they exhibited only utility value $3,58,59,67,71,78,80-82,88,90,91$ because connection with professional organisation was lacking. ${ }^{3,59}$ Interestingly, another group of HPs reported high confidence/competence levels, but they were negative and feared research. ${ }^{53,77,89}$ The reason for this attitude was the perception that research was not part of their job roles and there was no organisational support, so they did not see the connection with the research community. ${ }^{53}$ This same reason was observed for HPs who lacked confidence, had no prior exposure and had negative attitude towards research. ${ }^{54,63,74,76}$ They perceived that it had no value and involved a lot of personal cost for limited personal gain. ${ }^{76}$ Others lacked confidence but because of their predisposing personal qualities and exposure to research, which was facilitated by workplace research opportunities, they had positive attitude towards research. ${ }^{16,55,68,84-87}$

Overall, the type of value attributed to research directly influenced the relevance of barriers and affected motivation to participate in research. As shown in Figure 2, participants who were very positive displayed an attitude inclusive of attainment, intrinsic and utility values as well as connectedness to research and were able to overcome the barriers relating to cost with a display of great autonomy. HPs who were positive but lacking confidence/requiring support, mainly subscribed to utility values and were limited by the burden of barriers. HPs who reported low expectancy and competence, exhibited total lack of value for research, had no sense of belonging or attachment to researchers in their organisations, focused on the barriers/ limitations and therefore had no interest to undertake research. These findings indicate that prior exposure to research training increases expectancy and confidence, but type of value placed on research determines the strength of connection to research, and ability to disregard the myriads of challenges/barriers. High values foster on-going intrinsic commitment and long-term motivation to engage with research.

\section{Discussion}

Various strategies and assumptions have been made and tested regarding the reasons for the decline in the uptake/ continuation of research by HPs and how to build research capacity among HPs. ${ }^{3,7,55,61,96-98}$ Despite these efforts, little headway has been made which necessitates taking the opportunity of examining HPs engagement in research through a different lens. This review has explored the literature with a focus on understanding HPs' motivation to do research through the $\mathrm{EVC}^{33,34}$ and $\mathrm{SDT}^{40,41}$

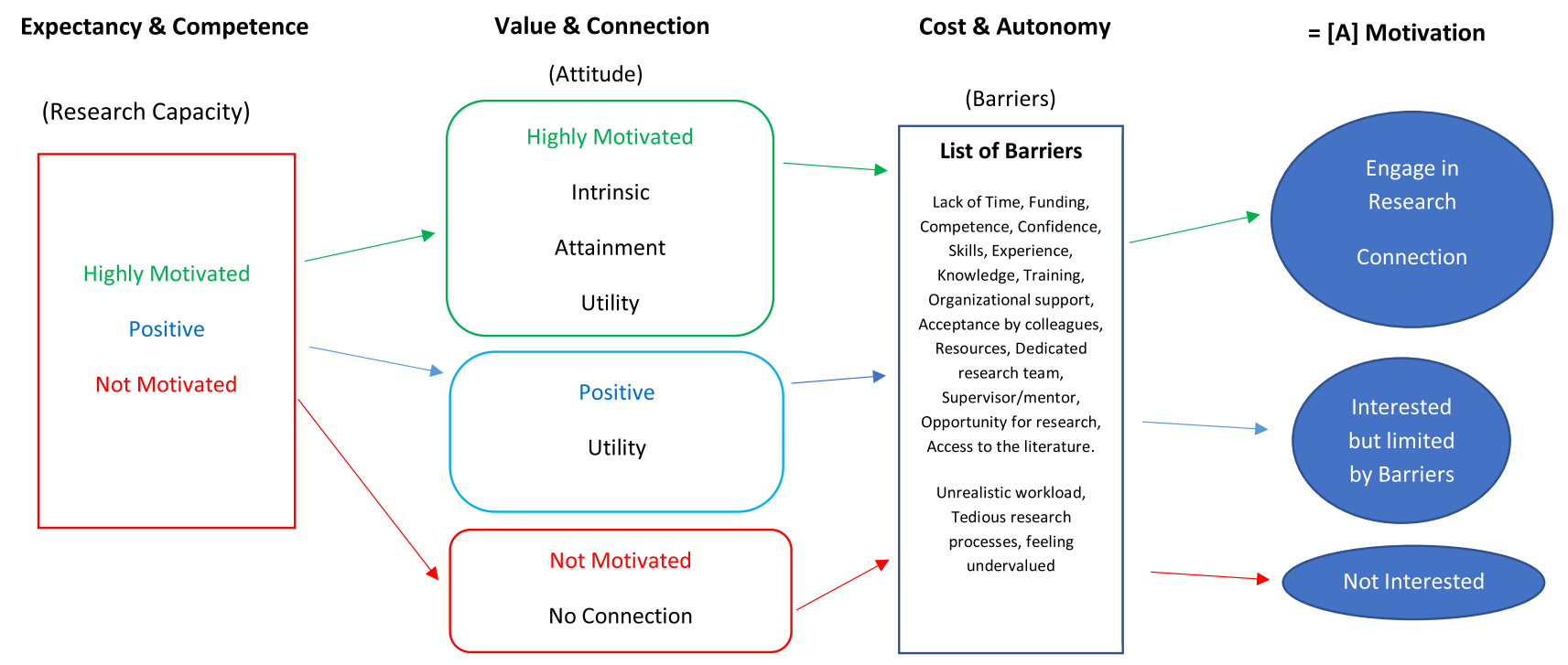

Figure 2 Process of motivation to do research. 
theoretical constructs and an investigation of expectancy, research capacity, attitude and barriers as precursors to motivation to undertake/continue with research. The elements in these theories have been used to understand the interactions and sequence of occurrence of themes to allow for long-term motivation to do research.

Based on SDT with its elements of competence, connection, and autonomy, the review findings posit that competence is enhanced if there is prior exposure to research in undergraduate/postgraduate space and this then influences graduates when they come into the workspace as it helps them to get that connection and a sense of belonging with other research active members of the organisation and that makes them feel that they are in control and they are able to keep going. ${ }^{41,44}$ However, if HPs have not had prior exposure to research and there is no perceived organisational support, they see the barriers or limitations more and that sometimes frightens them and stops them from engaging in research. ${ }^{44}$

EVC follows a similar pattern as it considers HPs' expectancy or anticipated ability to do research which is fostered by that confidence gained from prior exposure to research in their undergraduate/postgraduate years. Taking it one step further, EVC helps to unpack the importance of value that is attached to research. The findings from this review predicate that even when research training is strong, which is important for confidence building and expectancy to do well in research, what keeps HPs motivated and helps them to overlook or disregard the myriads of barriers is the kind of value they attach to research.

Factors which motivate and facilitate research by HPs are dependent on both extrinsic and intrinsic variables. ${ }^{49}$ These variables are dynamic in nature and are influenced at the individual, organisational and cultural level in a dynamic research ecosystem. ${ }^{98}$ In this review, in most cases those who were competent in their research capacity, with high expectations of success and had very positive attitude towards research demonstrated all three values attributed to doing research (intrinsic - personal enjoyment, utility - future usefulness and attainment - doing well). This group of HPs were keen to take up research despite the barriers. Those who had a positive attitude were only motivated to do research because of its utility value, although they did not necessarily see it as having personal relevance for themselves. ${ }^{57,61,88,90,93}$ Those who were unmotivated did not see any connection or relatedness to the research experience for themselves, felt it was too difficult and had very low ability beliefs which de- valued active participation in research..$^{54,74,76,77}$ Ability beliefs have been predicted to positively impact expectancy and research capacity, while task difficulty negatively impacts expectancy. ${ }^{33}$

The barriers to involvement in research which were identified in this review corroborate previous literature findings and centre around lack of knowledge and skills to conduct research, ${ }^{94,97}$ lack of protected research time, ${ }^{99,100}$ lack of funding ${ }^{69,101,102}$ and lack of support from colleagues, and the organisation. ${ }^{54,74,76,77}$ Clinical workloads take precedence over time available for research ${ }^{17,56}$ and this was confirmed in a recent Australian study which reported that $55 \%$ of research active doctors spend most of their time on clinical activities. ${ }^{3}$ Studies have also shown that research careers pay lower salary than clinical careers ${ }^{3,13}$ and offer lower job security relative to clinical careers. ${ }^{3,101}$ These issues are compounded by the difficulty in getting research grants ${ }^{13,32}$ and the lower funding rates available for research. ${ }^{3,102}$ Lack of resources was also a deterrent for otherwise motivated medical professionals to engage in research. ${ }^{16,32}$

The lack of support, acceptance by colleagues, reward and acknowledgement highlighted in this review can be attributed to lack of organisational support. Studies have shown that organisational challenges such as lack of acknowledgement and recognition of medical professionals undertaking a research role by their peers and by the organisation for which they work are significant barriers to research involvement. ${ }^{32,103}$ Several studies found that medical professionals had difficulty finding a mentor for their research project. ${ }^{102,104,105}$ In this review, for HPs who were negative, the emphasis was on the concept of lack of mentorship which would have offered a sense of connection to inspire an attitude of value (intrinsic, attainment, and/ or utility), boosting confidence and providing support for research participation.${ }^{106,107}$ Effective mentorship has been identified as vital for HPs undertaking research ${ }^{70,108,109}$ and an important contributor to research success. ${ }^{110}$ Mentoring programmes that support the health researcher with resources and expertise will optimise research training and research outcomes. ${ }^{60,111}$ Healthcare organisations in Australia, ${ }^{21}$ the US ${ }^{108,110,111}$ and the $\mathrm{UK}^{96}$ have been encouraged to include meaningful mentoring programmes into their research profile at all stages of the clinical academic training and career pathway from medical student, intern and pre-vocational doctor, vocational trainee, post-doctoral/early fellowships and definite appointment. ${ }^{21}$ Positive reinforcement by research active HPs is critical at all stages of the research training and career pipeline. ${ }^{3,112}$ An effective mentorship program is integral to 
establishing or building a research culture within the HPs' organisation. ${ }^{56}$ Conducive organisational research culture enhances research capacity building, which is enhanced by developing organisational structure, processes and systems, developing appropriate links with external partners and research career pathways ${ }^{16,94}$ to enable health researchers to conduct research in a safe, supportive and nurturing environment where research is valued and resourced. ${ }^{96,113}$ An organisational culture that supports research and enables building research capacity through supporting research training, quarantined time for research and adequate funding espouses the value of research which engenders connection. Overall, barriers impact on attitude to conduct research ${ }^{66,70,80,82-84,87-}$ 89,100 and by implication affect response to the cost of doing research and significantly contribute to undervaluing research. ${ }^{49,65}$

The concept of value in research is of primary importance and is an area that needs to be focused on, particularly during training. ${ }^{61,64}$ Emphasis should be placed on the value elements of motivation, with focus on attainment and intrinsic motivation. Explaining that value goes beyond the utility of research in clinical practice, is a useful way of introducing and developing an appreciation of attainment value which is about professional gains and fostering intrinsic value, which is about being involved in finding solutions to clinical problems as such an approach may keep HPs engaged in research. This strategy may be worthy of consideration by accrediting professional bodies, educational institutions, funding bodies and workplace organisations in their endeavours to foster uptake and retention of research activities by HPs.

Of all three HP groups, AHPs were the most lacking confidence and requiring support which may be attributed to having less research training and research experience than the other groups. Nonetheless, it is interesting to note that amongst the AHPs, the pharmacists were the most confident to undertake research. The findings of this systematic review also indicate that medical professionals, possibly due to their prior exposure to research training and research experience are in a better position than AHPs and nurses to overcome the barriers. Future studies could investigate how HPs navigate their way through barriers at different career stages - early, mid-career, late career. Future explorations could also consider whether the three HP groups (AHPs, medical doctors, nurses) follow similar or dissimilar trajectories in terms of how their research values change over their career stages.
The ability to accurately inform potential researchers regarding the attractions and barriers to health research in their careers, and to implement strategies to reverse current concerning trends in the decline of health professionals engaging in research will help to ensure HPs' leadership in HMR into the foreseeable future. Furthermore, utilisation of theoretical frameworks that inform processes and facilitate a culture of HP research would enable optimisation of health workforce research capability and high-quality care.

\section{Strengths and Limitations}

The major strength of this review is the integration of the EVC and SDT theories which offer an overarching construct that provide in-depth understanding into HPs' motivation to do research. Additionally, the quality appraisal of the reviewed articles provides evidence for the methodological rigour of the reviewed articles and strengthens the interpretation of the findings because all the articles were assessed as medium to high-quality studies. However, interpretation of the results must be applied cautiously due to some inherent limitations of the review. Generalisation of the findings may be limited by the authors' interpretation of the investigated research elements/domains in the reviewed papers. Other limitations of this review include the heterogeneity of the included studies and the possible exclusion of relevant studies due to the pre-set inclusion criteria.

\section{Conclusion}

Overall, this review provides good evidence for the practicality of EVC and SDT in understanding HPs' motivation to do research. In line with SDT elements, competence is enhanced by prior exposure to research training, and this enhances autonomy and connection with other research active members of the organisation. Similarly, EVC considers HPs' expectancy or anticipated ability to do research which is fostered by confidence gained from prior exposure to research. EVC further emphasises the impactful effect of the type of value attributed to research on the relevance HPs attach to the myriads of barriers they face and their motivation to engage in research. The findings from this systematic review indicate priority facilitators to research participation revolve around the themes of allocated time for research, funding, research training, strong organisational research culture and mentorship program. The importance of confidence building and the expectation to succeed leading to competency through 
research education and training is accentuated. Nonetheless, autonomy and on-going motivation to actively engage in research are mostly influenced by HPs' attitude vis-A-vis the three value components intrinsic attainment and utility. Therefore, emphasis on the value attributes of research may be worthy of note by accrediting professional bodies, educational institutions, funding bodies and workplace organisations as critical to the research pipeline and the motivation of HPs to undertake research.

\section{Acknowledgments}

The authors acknowledge Mr Chris Parker, Manager Library Services, the Prince Charles Hospital, Chermside, Queensland for his input in the development of the search strategy.

\section{Disclosure}

The authors report no conflicts of interest in this work.

\section{References}

1. Hay-Smith EJ, Brown M, Anderson L, Treharne GJ. Once a clinician, always a clinician: a systematic review to develop a typology of clinician-researcher dual-role experiences in health research with patient-participants. BMC Med Res Methodol. 2016;16:95. doi:10.1186/s12874-016-0203-6

2. Hall AK, Mills SL, Lund PK. Clinician-investigator training and the need to pilot new approaches to recruiting and retaining this workforce. Acad Med. 2017;92(10):1382-1389. doi:10.1097/ACM.000 0000000001859

3. Mills JMZ, Januszewski AS, Robinson BG, Traill CL, Jenkins AJ, Keech AC. Attractions and barriers to Australian physician-researcher careers: physician-researcher influences. Intern Med J. 2019;49 (2):171-181. doi:10.1111/imj.14086

4. Pang T, Sadana R, Hanney S, Bhutta ZA, Hyder AA, Simon J. Knowledge for better health: a conceptual framework and foundation for health research systems. Bull World Health Organ. 2003;81 (11):815-820.

5. Burns LJ, Clayton CP, George JN, Mitchell BS, Gitlin SD. The effect of an intense mentoring program on junior investigators' preparation for a patient-oriented clinical research career. Acad Med. 2015;90 (8):1061-1066. doi:10.1097/ACM.0000000000000742

6. Association of Australian Medical Research Institutes. Health research in Australia; 2020. Available from: https://aamri.org.au/health-medi cal-research/fast-facts-on-medical-research/. Accessed December 18, 2021.

7. Traill CL, Januszewski AS, Larkins R, Keech AC, Jenkins AJ. Time to research Australian physician-researchers. Intern Med J. 2016;46 (5):550-558. doi:10.1111/imj.13043

8. Wyngaarden JB. The clinical investigator as an endangered species. $N$ Engl J Med. 1979;301(23):1254-1259. doi:10.1056/NEJM1979120 63012303

9. Funston G, Piper RJ, Connell C, Foden P, Young AMH, O’Neill P. Medical student perceptions of research and research-orientated careers: an international questionnaire study. Med Teach. 2016;38 (10):1041-1048. doi:10.3109/0142159X.2016.1150981
10. McKinney RE. The daunting career of the physician-investigator. Acad Med. 2017;92(10):1368-1370. doi:10.1097/ACM.00000 00000001869

11. Deligiannidis KM. The physician-scientist workforce in the United States. Acta Psychiatr Scand. 2015;132(4):317-318. doi:10.1111/acps. 12435

12. National Institutes of Health. Physician-scientist workforce working group report; 2014. Available from: https://acd.od.nih.gov/ documents/reports/PSW_Report_ACD_06042014.pdf. Accessed December 18, 2021.

13. Lander B, Hanley GE, Atkinson-Grosjean J. Clinician-scientists in Canada: barriers to career entry and progress. PLoS One. 2010;5(10):04. doi:10.1371/journal.pone.0013168

14. McLean AL, Saunders C, Velu PP, Iredale J, Hor K, Russell CD. Twelve tips for teachers to encourage student engagement in academic medicine. Med Teach. 2013;35(7):549-554. doi:10.3109/0142159X.2013.775412

15. Karlsson L, Stockfelt M, Finizia C. Improved information in medical school may increase recruitment of physician-scientists. Lakartidningen. 2014;111(47):2108-2110.

16. Conradie A, Duys R, Forget P, Biccard BM. Barriers to clinical research in Africa: a quantitative and qualitative survey of clinical researchers in 27 African countries. Br J Anaesth. 2018;121 (4):813-821. doi:10.1016/j.bja.2018.06.013

17. Woo KT, Wong KS, Lee EJ, Chan CM. How can we improve clinical research in clinical practice with better research outcome? Ann Acad Med Singapore. 2011;40(11):499-506.

18. Anwer LA, Anwer AN, Mahmood M, Abu-Zaid A, Shareef MA. Meeting the global need for physician-scientists: a Middle Eastern imperative. Med. 2014;19:26138.

19. Abu-Zaid A. The endangered clinician-investigator profession in Saudi Arabia: curricular attention is required. Ann Saudi Med. 2018;38(1):69-70. doi:10.5144/0256-4947.2018.69

20. Jain MK, Cheung VG, Utz PJ, Kobilka BK, Yamada T, Lefkowitz R. Saving the endangered physician-scientist - a plan for accelerating medical breakthroughs. $N$ Engl J Med. 2019;381(5):399402. doi:10.1056/NEJMp1904482

21. Windsor J, Garrod T, Talley NJ, et al. The clinical academic workforce in Australia and New Zealand: report on the second binational summit to implement a sustainable training pathway: sustainable clinical academic workforce. Intern Med J. 2017;47 (4):394-399. doi:10.1111/imj.13356

22. Al-Busaidi IS, Tarr GP. Dissemination of results from medical student public health research training and factors associated with publication. Postgrad Med J. 2018;94(1112):330-334. doi:10.1136/postgradmedj-2017-135361

23. Al-Busaidi IS, Wells CI. Stimulating the clinical academics of tomorrow: a survey of research opportunities for medical students in New Zealand. $N$ Z Med J. 2017;130(1462):80-88.

24. Australian Institute of Health and Welfare. Medical labor force 2002. Canberra: Australian Institute of Health and Welfare; 2004. Available from: https://www.aihw.gov.au/reports/workforce/medi cal-labour-force-2002/formats. Accessed December 18, 2021.

25. Australian Institute of Health and Welfare. Medical workforce 2010. Canberra: Australian institute of Health and Welfare; 2012. Available from: https://www.aihw.gov.au/getmedia/ 75c1aba7-71b3-4844-bd8c-9afad41e8287/14055.pdf.aspx?inline= true. Accessed December 18, 2021.

26. Medical Deans Australia and New Zealand (MDANZ). Medical schools outcomes database national data report 2013-2017. Sydney, NSW: Medical Deans Australia and New Zealand; 2018. Available from: https://medicaldeans.org.au/md/2019/09/ 2018-MSOD-Final-report.pdf. Accessed December 18, 2021.

27. Pain K, Hagler P, Warren S. Development of an instrument to evaluate the research orientation of clinical professionals. Can $J$ Rehabil. 1996;9(2):93-100. 
28. Traill CL, Januszewski AS, Larkins RG, Keech AC, Jenkins AJ. Time to research Australian female physician-researchers. Intern Med J. 2016;46(4):412-419. doi:10.1111/imj.12986

29. Pain T, Plummer D, Pighills A, Harvey D. Comparison of research experience and support needs of rural versus regional allied health professionals. Aust J Rural Health. 2015;23(5):277285. doi:10.1111/ajr.12234

30. Hulcombe J, Sturgess J, Souvlis T, Fitzgerald C. An approach to building research capacity for health practitioners in a public health environment: an organisational perspective. Austr Health Rev. 2014;38(3):252-258. doi:10.1071/AH13066

31. Harding K, Lynch L, Porter J, Taylor NF. Organisational benefits of a strong research culture in a health service: a systematic review. Aust Health Rev. 2017;41(1):45-53. doi:10.1071/AH15180

32. Jones RD, Griffith KA, Ubel PA, Stewart A, Jagsi R. A mixedmethods investigation of the motivations, goals, and aspirations of male and female academic medical faculty. Acad Med. 2016;91 (8):1089-1097. doi:10.1097/ACM.0000000000001244

33. Eccles JS, Adler TF, Futterman R, et al. Expectancies values and academic behaviors. In: Spence J, editor. Achievement and Achievement Motives. San Francisco, CA: W H Freeman; 1983:74-146.

34. Eccles JS, Wigfield A. Motivational beliefs, values, and goals. Annu Rev Psychol. 2002;53(1):109-132. doi:10.1146/annurev. psych.53.100901.135153

35. Wigfield A, Eccles JS. Expectancy-value theory of achievement motivation. Contemp Educ Psychol. 2000;25(1):68-81. doi:10.1006/ceps.1999.1015

36. Nikkar-Esfahani A, Jamjoom AA, Fitzgerald JE. Extracurricular participation in research and audit by medical students: opportunities, obstacles, motivation and outcomes. Med Teach. 2012;34 (5):e317-24. doi:10.3109/0142159X.2012.670324

37. Griffin MF, Hindocha S. Publication practices of medical students at British medical schools: experience, attitudes and barriers to publish. Med Teach. 2011;33(1):e1-8. doi:10.3109/ 0142159X.2011.530320

38. Orsini C, Binnie VI, Wilson SL. Determinants and outcomes of motivation in health professions education: a systematic review based on self-determination theory. J Educ Eval Health Prof. 2016;13:19. doi:10.3352/jeehp.2016.13.19

39. Robinson GF, Switzer GE, Cohen ED, et al. Shortening the work preference inventory for use with physician scientists: WPI-10. Clin Transl Sci. 2014;7(4):324-328. doi:10.1111/cts.12132

40. Ryan R. Self determination theory and well being. Soc Psychol. 2009;84(822):848.

41. Ryan RM, Deci EL. Self-Determination Theory: Basic Psychological Needs in Motivation, Development, and Wellness. New York: Guilford Press; 2017.

42. Bernard D, Martin JJ, Kulik N. Self-determination theory and well-being in the health care profession. J Appl Biobehav Res. 2014;19(3):157-170. doi:10.1111/jabr.12023

43. Deci EL, Olafsen AH, Ryan RM. Self-determination theory in work organizations: the state of a science. Annu Rev Organ Psychol Organ Behav. 2017;4:19-43. doi:10.1146/annurev-orgpsych-032516-113108

44. Self-determination theory of motivation: why intrinsic motivation matters; 2019. Available from: https://positivepsychology.com/ self-determination-theory/. Accessed December 18, 2021.

45. Moher D, Liberati A, Altman D, Tetzlaff J, et al. The PRISMA statement for reporting systematic reviews and meta-analyses of studies that evaluate health care interventions: explanation and elaboration, Journal of clinical epidemiology. 2009;62(10).

46. Barron KE, Hulleman CS. Expectancy-value-cost model of motivation. In: Wright JD, editor. International Encyclopedia of the Social \& Behavioral Sciences. 8. 2nd ed. Oxford: Elsivier; 2015:503-509.
47. Krippendorff K. Content Analysis: An Introduction to Its Methodology. 2nd ed. Thousand Oaks, Calif.: Sage; 2004.

48. Allen M. The Sage Encyclopedia of Communication Research Methods. Thousand Oaks, CA: SAGE Publication; 2017.

49. Matus J, Walker A, Mickan S. Research capacity building frameworks for allied health professionals - a systematic review. BMC Health Serv Res. 2018;18. doi:10.1186/s12913-018-3518-7

50. Sirriyeh R, Lawton R, Gardner P, Armitage G. Reviewing studies with diverse designs: the development and evaluation of a new tool. J Eval Clin Pract. 2012;18(4):746-752. doi:10.1111/j.13652753.2011.01662.x

51. White G. Producing and utilising research: barriers for a nursing faculty in Oman. Middle East $J$ Nurs. 2013;7(2):3-8. doi:10.5742/MEJN.2013.72223

52. Borkowski D, McKinstry C, Cotchett M. Research culture in a regional allied health setting. Aust J Prim Health. 2017;23 (3):300-306. doi:10.1071/PY16085

53. Elphinston RA, Pager S. Untapped potential: psychologists leading research in clinical practice. Aust Psychol. 2015;50(2):115121. doi:10.1111/ap.12102

54. Finch E, Cornwell P, Nalder E, Ward E. Uncovering motivators and stumbling blocks: exploring the clinical research experiences of speech-language pathologists. Int J Speech Lang Pathol. 2015;17(2):138-147. doi:10.3109/17549507.2014.930175

55. Harvey D, Plummer D, Nielsen I, Adams R, Pain T. Becoming a clinician researcher in allied health. Aust Health Rev. 2016;40 (5):562. doi:10.1071/AH15174

56. Hiscock H, Ledgerwood K, Danchin M, Ekinci E, Johnson E, Wilson A. Clinical research potential in Victorian hospitals: the Victorian clinician researcher needs analysis survey. Intern Med J. 2014;44(5):477-482. doi:10.1111/imj.12396

57. McMaster R, Jammali-Blasi A, Andersson-Noorgard K, Cooper $\mathrm{K}$, McInnes E. Research involvement, support needs, and factors affecting research participation: a survey of Mental Health Consultation Liaison Nurses. Int J Ment Health Nurs. 2013;22 (2):154-161. doi:10.1111/j.1447-0349.2012.00857.x

58. McNab M, Berry A, Skapetis T. The potential of a lecture series in changing intent and experience among health professionals to conduct research in a large hospital: a retrospective pre-post design. BMC Med Educ. 2019;19(1):124. doi:10.1186/s12909-019-1548-4

59. Oliver-Baxter J, Brown L, McIntyre E. Surviving or thriving in the primary health care research workforce: the Australian experience. Aust J Prim Health. 2017;23(2):183-188. doi:10.1071/PY15190

60. Pager S, Holden L, Golenko X. Motivators, enablers, and barriers to building allied health research capacity. J Multidiscip Healthc. 2012;5:53-59. doi:10.2147/JMDH.S27638

61. Pain T, Petersen M, Fernando M. Building allied health research capacity at a regional Australian hospital: a follow-up study. Internet J Allied Health Sci Pract. 2018;16(4):1-10.

62. Wenke R, Mickan S, Bisset L. A cross sectional observational study of research activity of allied health teams: is there a link with self-reported success, motivators and barriers to undertaking research? BMC Health Serv Res. 2017;17:1-10. doi:10.1186/ s12913-017-1996-7

63. Wenke R, Noble C, Weir KA, Mickan S. What influences allied health clinician participation in research in the public hospital setting: a qualitative theory-informed approach. BMJ Open. 2020;10(8):e036183. doi:10.1136/bmjopen-2019-036183

64. Alison JA, Zafiropoulos B, Heard R. Key factors influencing allied health research capacity in a large Australian metropolitan health district. J Multidiscip Healthc. 2017;10:277. doi:10.2147/ JMDH.S142009

65. Marshall AP, Roberts S, Baker MJ, et al. Survey of research activity among multidisciplinary health professionals. Aust Health Rev. 2016;40(6):667-673. doi:10.1071/AH15156 
66. Paget SP, Lilischkis KJ, Morrow AM, Caldwell PH. Embedding research in clinical practice: differences in attitudes to research participation among clinicians in a tertiary teaching hospital. Intern Med J. 2014;44(1):86-89. doi:10.1111/imj.12330

67. Albert NM, Rice KL, Waldo MJ, et al. Clinical nurse specialist roles in conducting research: changes over 3 years. Clin Nurse Spec. 2016;30(5):292-301. doi:10.1097/NUR.00000000 00000236

68. Chan GK, Barnason S, Dakin CL, et al. Barriers and perceived needs for understanding and using research among emergency nurses. $J$ Emerg Nurs. 2011;37(1):24-31. doi:10.1016/j. jen.2009.11.016

69. Cianciolo AT, Mitzelfelt J, Ghareeb A, Zahid MF, Akbar R, Ghias K. Physician-scientist or basic scientist? Exploring the nature of clinicians' research engagement. Adv Health Sci Educ. 2020;26:353-367.

70. Mansi A, Karam WN, Chaaban MR. Attitudes of residents and program directors towards research in otolaryngology residency. Ann Otol Rhinol Laryngol. 2019;128(1):28-35. doi:10.1177/ 0003489418804565

71. Scala E, Patterson BJ, Stavarski DH, Mackay P. Engagement in research: a clinical nurse profile and motivating factors. $J$ Nurses Prof Dev. 2019;35(3):137-143. doi:10.1097/NND.00000000 00000538

72. Siedlecki S, Albert N. Research-active clinical nurses: against all odds. J Clin Nurs. 2016;26:766-773. doi:10.1111/jocn.13523

73. Silberman EK, Belitsky R, Bernstein CA, et al. Recruiting researchers in psychiatry: the influence of residency vs early motivation. Acad Psychiatry. 2012;36(2):85-90. doi:10.1176/ appi.ap. 10010010

74. Bench S, Dowie-Baker JA, Fish P. Orthopaedic nurses' engagement in clinical research; an exploration of ideas, facilitators and challenges. Int $J$ Orthop Trauma Nurs. 2019;35:100699. doi:10.1016/j.ijotn.2019.04.002

75. Connolly B, Allum L, Shaw M, Pattison N, Dark P. Characterising the research profile of the critical care physiotherapy workforce and engagement with critical care research: a UK national survey. BMJ Open. 2018;8(6):e020350. doi:10.1136/ bmjopen-2017-020350

76. Lowrie R, Morrison G, Lees R, et al. Research is 'a step into the unknown': an exploration of pharmacists' perceptions of factors impacting on research participation in the NHS. BMJ Open. 2015;5(12):e009180. doi:10.1136/bmjopen-2015-009180

77. Snelgrove S, James M. Graduate nurses' and midwives' perceptions of research. J Res Nurs. 2011;16(1):7-20. doi:10.1177/ 1744987110387484

78. Stewart D, Cunningham S, Strath A, et al. A theoretically informed survey of the views and experiences of practicing pharmacists on research conduct, dissemination and translation. Res Social Adm Pharm. 2019;15(11):1298-1308. doi:10.1016/j. sapharm.2018.12.005

79. Luckson M, Duncan F, Rajai A, Haigh C. Exploring the research culture of nurses and allied health professionals (AHPs) in a research-focused and a non-research-focused healthcare organisation in the UK. J Clin Nurs. 2018;27:E1462-E76. doi:10.1111/ jocn. 14264

80. Sarwar MR, Saqib A, Riaz T, Aziz H, Arafat M, Nouman H. Attitude, perception, willingness, motivation and barriers to practice-based research: a cross-sectional survey of hospital pharmacists in Lahore, Punjab, Pakistan. PLoS One. 2018;13(9): e0203568. doi:10.1371/journal.pone.0203568

81. Stewart D, Al Hail M, Abdul Rouf PV, et al. Building hospital pharmacy practice research capacity in Qatar: a cross-sectional survey of hospital pharmacists. Int J Clin Pharm. 2015;37 (3):511-521. doi:10.1007/s11096-015-0087-2
82. Sultana K, Al Jeraisy M, Al Ammari M, Patel R, Zaidi STR Attitude, barriers and facilitators to practice-based research: cross-sectional survey of hospital pharmacists in Saudi Arabia. J Pharm Policy Pract. 2016;9(1):4. doi:10.1186/ s40545-016-0052-z

83. Akerjordet K, Lode K, Severinsson E. Clinical nurses' attitudes towards research, management and organisational resources in a university hospital: part 1. J Nurs Manag. 2012;20(6):814-823. doi:10.1111/j.1365-2834.2012.01477.x

84. Berthelsen CB, Holge-Hazelton B. Orthopaedic nurses' attitudes towards clinical nursing research - a cross-sectional survey. Int $J$ Orthop Trauma Nurs. 2015;19(2):74-84. doi:10.1016/j. ijotn.2014.10.004

85. Dannapfel P, Peolsson A, Nilsen P. What supports physiotherapists' use of research in clinical practice? A qualitative study in Sweden. Implement Sci. 2013;8:31. doi:10.1186/1748-5908-8-31

86. Dannapfel P, Peolsson A, Stahl C, Oberg B, Nilsen P. Applying self-determination theory for improved understanding of physiotherapists' rationale for using research in clinical practice: a qualitative study in Sweden. Physiother. 2014;30(1):20-28.

87. Mahmoud AO, Ayanniyi AA, Lawal A, Omolase CO, Ologunsua Y, Samaila E. Survey of medical specialists on their attitudes to and resources for health research in Nigeria. Ann Afr Med. 2011;10(2):144-149. doi:10.4103/1596-3519.82078

88. van Hoving DJ, Brysiewicz P. African emergency care providers' attitudes and practices towards research. Afr J Emerg Med. 2017;7 (1):9-14. doi:10.1016/j.afjem.2017.01.003

89. Choo TL, Muninathan P, Pung CM, Ramanathan GRL. Attitudes, barriers and facilitators to the conduct of research in government hospitals: a cross-sectional study among specialists in government hospitals, northern states of Malaysia. Med J Malaysia. 2017;72 (1):26-31.

90. Torres GCS, Estrada MG, Sumile EFR, Macindo JRB, Maravilla SN, Hendrix CC. Assessment of research capacity among nursing faculty in a clinical intensive university in the Philippines. Nurs Forum. 2017;52(4):244-253. doi:10.1111/nuf.12192

91. Ito-Ihara T, Hong JH, Kim OJ, et al. An international survey of physicians regarding clinical trials: a comparison between Kyoto University Hospital and Seoul National University Hospital. BMC Med Res Methodol. 2013;13:130. doi:10.1186/1471-2288-13-130

92. McDonald E, Zytaruk N, Heels-Ansdell D. Motivators and stressors for Canadian research coordinators in critical care: the motivate survey. Am J Crit Care. 2020;29(1):41-48. doi:10.4037/ ajcc2020627

93. Janssen J, Hale L, Mirfin-Veitch B, Harland T. Perceptions of physiotherapists towards research: a mixed methods study. Physiotherapy. 2016;102(2):210-216. doi:10.1016/j. physio.2015.04.007

94. Borkowski D, McKinstry C, Cotchett M, Williams C, Haines T. Research culture in allied health: a systematic review. Aust J Prim Health. 2016;22(4):294-303. doi:10.1071/PY15122

95. Pager S, Pager S. A team effort: enabling rehabilitation professional research in the real world. Int $J$ Ther Rehabil. 2014;21 (3):107. doi:10.12968/ijtr.2014.21.3.107

96. Lingard L, Zhang P, Strong M, Steele M, Yoo J, Lewis J. Strategies for supporting physician-scientists in faculty roles: a narrative review with key informant consultations. Acad Med. 2017;92(10):1421-1428. doi:10.1097/ACM.0000000000001868

97. Gardner A, Smyth W, Renison B, Cann T, Vicary M. Supporting rural and remote area nurses to utilise and conduct research: an intervention study. Collegian. 2012;19(2):97-105. doi:10.1016/j. colegn.2011.09.005

98. Slade SC, Philip K, Morris ME. Frameworks for embedding a research culture in allied health practice: a rapid review. Health Res Policy Syst. 2018;16:1. doi:10.1186/s12961-018-0304-2 
99. Noble C, Billett SR, Phang DTY, Sharma S, Hashem F, Rogers GD. Supporting resident research learning in the workplace: a rapid realist review. Acad Med. 2018;93:1732-1740. doi:10.1097/ ACM.0000000000002416

100. Siemens DR, Punnen S, Wong J, Kanji N. A survey on the attitudes towards research in medical school. BMC Med Educ. 2010;10:4. doi:10.1186/1472-6920-10-4

101. Ganetzky RD. Becoming a physician-scientist: a view looking up from base camp. Acad Med. 2017;92(10):1373-1374. doi:10.1097/ACM.0000000000001876

102. Saeed I, Khan NF, Bari A, Khan RA. Factors contributing to the lack of interest in research activities among postgraduate medical students. Pak J Med Sci. 2018;34(4):913-917. doi:10.12669/ pjms.344.15411

103. Rahman S, Majumder MAA, Shaban SF, et al.Physician participation in clinical research and trials: issues and approaches. Adv Med Educ Pract. 2011;(default):85. doi:10.2147/AMEP. S14103

104. Hirschtritt ME, Heaton PM, Insel TR. Preparing physician-scientists for an evolving research ecosystem. JAMA. 2018;320(1):3132. doi:10.1001/jama.2018.4478

105. Kwan JM, Daye D, Schmidt ML, et al. Exploring intentions of physician-scientist trainees: factors influencing $\mathrm{MD}$ and $\mathrm{MD} / \mathrm{PhD}$ interest in research careers. BMC Med Educ. 2017;17(1):115. doi:10.1186/s12909-017-0954-8

106. Deci EL, Ryan RM. Intrinsic Motivation and Self-Determination in Human Behavior. 1re ed. New York: Plenum; 1985:xv, 371.
107. Deci EL, Ryan RM. The 'what' and 'why' of goal pursuits: human needs and the self-determination of behavior. Psychol Inq. 2000;11(4):227-268. doi:10.1207/S15327965PLI1104_01

108. Byington CL, Keenan H, Phillips JD, et al. A matrix mentoring model that effectively supports clinical and translational scientists and increases inclusion in biomedical research: lessons from the university of Utah. Acad Med. 2016;91(4):497-502. doi:10.1097/ ACM.0000000000001021

109. Sng JH, Pei Y, Toh YP, Peh TY, Neo SH, Krishna LKR. Mentoring relationships between senior physicians and junior doctors and/or medical students: a thematic review. Med Teach. 2017;39(8):866-875. doi:10.1080/0142159X.2017.1332360

110. Yin HL, Gabrilove J, Jackson R, et al. Sustaining the clinical and translational research workforce: training and empowering the next generation of investigators. Acad Med. 2015;90(7):861865. doi:10.1097/ACM.0000000000000758

111. Daye D, Patel CB, Ahn J, Nguyen FT. Challenges and opportunities for reinvigorating the physician-scientist pipeline. J Clin Invest. 2015;125(3):883-887. doi:10.1172/JCI80933

112. Steer CJ, Jackson PR, Hornbeak H, McKay CK, Sriramarao P, Murtaugh MP. Team science and the physician-scientist in the age of grand health challenges. Ann N Y Acad Sci. 2017;1404(1):3-16. doi:10.1111/nyas. 13498

113. Gallagher R, Sadler L, Kirkness A, Belshaw J, Roach K, Warrington D. Collaboration: a solution to the challenge of conducting nursing research in cardiac rehabilitation. Collegian. 2013;20(4):255-259. doi:10.1016/j.colegn.2012.11.003
Journal of Multidisciplinary Healthcare

\section{Publish your work in this journal}

The Journal of Multidisciplinary Healthcare is an international, peerreviewed open-access journal that aims to represent and publish research in healthcare areas delivered by practitioners of different disciplines. This includes studies and reviews conducted by multidisciplinary teams as well as research which evaluates the results or conduct of such teams or healthcare processes in general. The journal

\section{Dovepress}

covers a very wide range of areas and welcomes submissions from practitioners at all levels, from all over the world. The manuscript management system is completely online and includes a very quick and fair peer-review system. Visit http://www.dovepress.com/testimonials. php to read real quotes from published authors. 